\title{
Post-acquisition performance of private acquirers
}

\section{Andrey Golubov *}

Rotman School of Management

University of Toronto

andrey.golubov@rotman.utoronto.ca
Nan Xiong

Surrey Business School

University of Surrey

n.xiong@surrey.ac.uk

${ }^{*}$ Corresponding author 


\begin{abstract}
We provide the first evidence on the performance of private operating firms as acquirers. Private bidders experience greater post-acquisition operating performance improvements compared to public bidders. This effect is not due to differences in target types, merger accounting, financing constraints, private equity ownership or subsequent listing of some private bidders, and is robust to instrumentation. Further analysis of governance arrangements at least partially attributes the private bidder effect to lower agency costs in private firms. Not only do private firms pay lower prices for target firm assets, they also operate them more efficiently by containing overhead costs and capital expenditures.
\end{abstract}

Keywords: private firms, mergers and acquisitions, operating performance improvements, agency conflicts

\title{
JEL Classification: G34
}

\section{Introduction}

Corporate takeovers are among the largest forms of corporate investment that a firm may undertake. For instance, corporations have spent US\$5 trillion on deals worldwide in the year 2015 alone, amounting to $6.8 \%$ of world GDP. ${ }^{1}$ Given the size and importance of this market, the performance of acquiring firms has received considerable attention in the academic literature. The extant empirical evidence shows that shareholders of acquiring firms earn, on average, close-to-zero and often negative abnormal returns around the time of takeover announcement, and that operating performance improvements often fail to materialize. ${ }^{2}$ However, virtually all of the existing evidence on acquirer performance is based on public 
acquiring firms. There is no evidence on the success of acquisitions made by private operating firms (not to be confused with private equity buyouts), which represent a large portion of the real economy and a sizeable fraction of the mergers and acquisitions (M\&A) market. Such undersampling has the potential to skew our understanding of takeovers (Netter, Stegemoller, and Wintoki (2011)).

In this paper we provide the first evidence on acquisition-related performance of private operating firms and compare it to that of public acquirers. Because private firms exhibit less separation of ownership and control, classic agency theory would predict that efficiency gains as a motive for acquisitions should be more prevalent - and empire-building less prevalent - in private firms as compared to public companies. However, it is also possible that higher agency costs in public firms are offset by benefits such as easier access to capital, monitoring by analysts and the marketfor corporate control, learning from stock prices, attracting better managerial talent, and optimal diversification of shareholders' portfolios. Whether private

\footnotetext{
${ }^{1}$ Source: Thomson Reuters SDC and International Monetary Fund.

${ }^{2}$ Many recent papers provide abnormal return estimates for takeover announcements, including Fuller, Netter, and Stegemoller (2002), Moeller, Schlingemann, and Stulz (2004, 2005), Masulis, Wang, and Xie (2007), and Golubov, Yawson, and Zhang (2015). Operating performance improvements are studied in Healy, Palepu, and Ruback (1992), Harford (1999), Ghosh (2001), Heron and Lie (2002). See also a review by Betton, Eckbo, and Thorburn (2008).
} 
or public firms generate greater efficiencies from their acquisitions is thus an open empirical question.

Webring this question to the data on both public and large private firms in the U.S. While data on private firms are generally unavailable, we take advantage of the fact that certain private firms are required to disclose their financials to the U.S. Securities and Exchange Commission (SEC) because of the size of their assets or because they have publicly traded debt. Although not representative of atypical privatefirm, these privatefirms are observably comparableto public firms in terms of size and information availability through 10-Kfilings.

Our analysis is based on a sample of 8,803 acquisition deals over the period 1997-2014 drawn from Capital IQ, of which roughly $15 \%$ were undertaken by private operating firms and the remainder by public bidders. Because the firm's listing status is likely endogenous, ourtests are designed to address the associated identification challenges. Forthemajority of our analysis we rely on state-of-the-art matching techniques and compare privatebidders to public bidders with the closest propensity to be private based on observable characteristics, disregarding public bidders that are too dissimilar. We also instrument listing status with venture capital availability in the firm's headquarter state during its early years, as in Asker, Farre-Mensa, and Ljungqvist (2015).

We find that, on average, private bidders exhibit positive operating performance improvements around acquisition deals, whereas operating performance changes for public bidders are mostly negative. Specifically, private bidders increase their return on assets (ROA) by $3-8 \%$ in the three years following the completion of the deal, while public bidders see a modest decline in their ROA of between zero and $2 \%$. Industry- or control-firm adjustment of the performance metrics makes little difference to these magnitudes. Asset utilization rates, as measured by asset turnover (ATO), follow similar patterns.

Consistent with our agency-based prediction, differences in operating performance changes between private and public bidders are positive and statistically significant. Further regres- 
sion adjustment of our estimates confirms that the private bidder effect survives controls for acquiring firm's size, prior performance and acquisition experience, growth opportunities (age), target firm type (public versus private), relative deal size, industry relatedness, hostility, and cross-border status. That is, differences in operating performance changes are not picking up observable differences in bidder, target, or deal types.

Next we test whether the private bidder effect can indeed be attributed to differences in agency costs using firm-level data on governance arrangements of public and private firms in our sample. We take advantage of Capital IQ's coverage of antitakeover defences ${ }^{3}$ and complement these data with hand-collected information on CEO ownership and ownership concentration byoutside shareholders for both public and private firms. As anticipated, private bidders employ significantly fewer provisions limiting shareholder control and exhibit greater levels of CEO ownership and ownership concentration by the largest shareholders. We find that the private bidder effect is driven by private bidders with higher CEO ownership, higher ownership concentration by outside shareholders, and fewer takeover defences. Thus, the evidence is consistent with the agency cost/incentive alignment channel behind the private bidder effect. We also explore the sources of superior operating performance changes in private bidders and find that they come from better containing overhead costs and capital expenditures.

Finally, we rule out several alternative explanations for the private bidder effect. First, it is possible that private bidders simply go after targets with higher levels of ROA/ATO than target firms acquired by public firms, resulting in greater combined firm profitability. This does not appear to be the case. In the subsample of deals where the target firms' financials are available, we show that targets of private bidders are not more profitable than those of public bidders. ${ }^{4}$ A second potential explanation has to do with merger accounting. If

\footnotetext{
${ }^{3}$ Note that most of our private bidders have more than 500 shareholders, rendering takeover defences relevant even for private firms. In addition, these provisions capture limitations to shareholder control more broadly, beyond takeover situations.

${ }^{4}$ In addition, if targets of private bidders were more profitable, this would be reflected in higher prices
} 
public bidders pay higher prices for targetfirm assets (as shown by Bargeron, Schlingemann, Stulz, and Zutter (2008) for public targets), then more accounting goodwill is created in acquisitions by public firms, resulting in higher book value of assets of the combined firm. Holding cashflows constant, a larger denominator in ROA and ATO ratios leads to lower post-deal ROA and ATO of the combined firm, potentially underestimating performance improvements of public bidders. We examine transaction multiples (EV/Book, EV/Sales, EV/EBITDA) paid by private versus public bidders, and find that private bidders, indeed, pay lower prices for target firm assets. However, we show a similar private bidder effect on post-takeover performance when using changes in return on sales ( $\Delta$ ROS) - a measure of performance improvement that is free from merger accounting effects. A third possibility we consider is that private firms are financially constrained and can only finance their best acquisition, whereas public firms can finance more marginal deals, resulting in lower average gains in profitability for public firms. However, we are able to rule this explanation out by showing that the private bidder effect is driven by firms that are characterized as less financially constrained.

While our matching-based and IV-based tests partly assuage concerns regarding endogeneity of a firm's listing status, we acknowledge a potential sample selection issue that remains. As noted at the outset, private firms in Capital IQ are not representative of a typical privatefirm in the economy. Therefore, our results are not immediately generalizable to the overall population of privately-owned companies. However, to the extent that lower agency conflicts is the channel behind the private bidder effect (as we have shown), a typical private firm exhibits even less separation of ownership and control than the private firms we study. We also note that data limitations preclude us from distinguishing between different types of private firm ownership (e.g. family-owned versus venture-capital-owned), meaning that our set of private firms likely exhibits considerable heterogeneity in terms of corporate

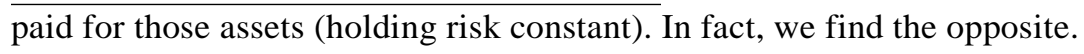


governance arrangements, some of which may not be superior to those in public firms.

This paper contributes to the M\&A literature by providing the first evidence on the performance of acquisitions made by private operating firms. Our results thus complement prior research that was limited to public acquirers. ${ }^{5}$ Moreover, our findings help interpret some of the prior results in this literature. In particular, Bargeron, Schlingemann, Stulz, and Zutter (2008) show that private firms pay lower premia relative to public bidders - a result we confirm in a broader sample of deals using transaction multiples. There are two possibilities: either private firms are more disciplined due to better incentive alignment, or they simply enter deals with lower synergy gains that would naturally warrant lower prices. Our results on greater operating performance improvements suggest it is the former case, and further demonstrate that, not only do private bidders pay lower prices for target firm assets, they also operate those assets more efficiently. Finally, our paper contributes to the nascent literaturethat studies the characteristics of privatefirms(Brav(2009), Saunders and Steffen (2011), Michaely and Roberts (2012), Gao, Harford, and Li (2013), Asker, Farre-Mensa, and Ljungqvist (2015), Bernstein (2015), Sacchetto and Xiong (2018)). We expand this set of studies by providing new evidence on the effect of private ownership on post-acquisition performance, and, by extension, on the quality of private firms' investment decisions more broadly.

The rest of the paper proceeds as follows. Section 2 develops our hypotheses in light of related studies. Section 3 describes our sample. Our empirical analysis is presented in Sections 4 and 5. We consider alternative explanations in Section 6. Section 7 concludes the paper.

\footnotetext{
${ }^{5}$ The only exception is a study by Maksimovic, Phillips, and Yang (2013) who use plant-level data for U.S. manufacturing firms to study public and private firm participation in merger waves. They show, among others, that productivity gains (measured by total factor productivity) following plant acquisitions are greater when the buyer is public. Our results are not necessarily in conflict, because i) our sample is not limited to manufacturing firms, and ii) we measure efficiency gains as changes in overall operating profitability at the firm level, which takes account of various expenses not captured in total factor productivity.
} 


\section{Hypotheses development and related studies}

\subsection{Hypotheses development}

A large literature examines takeover gains to acquiring firms, though virtually all papers are limited to studying public acquirers and use abnormal stock returns to measure takeover gains (see Betton, Eckbo, and Thorburn (2008) and Mulherin, Netter, and Poulsen (2017) for summaries of this literature). In general, evidence on the ability of acquiring firms to generate value through takeovers has been mixed. Fuller, Netter, and Stegemoller (2002) study abnormal returns for public firms that acquired five or more targets within a threeyear period, showing that public acquirers gain when buying a private or subsidiary firm, but lose or break-even when buying a public firm. In a sample of acquisitions by public firms from 1980 to 2001, Moeller, Schlingemann, and Stulz (2005) show that acquiring-firm shareholders lose $\$ 25.2$ million on average upon announcement.

One of the main hypotheses put forward to explain lacklustre acquirer performance is agency-driven empire-building and overpayment. As public firms are subject to considerable separation of ownership and control, they suffer from agency costs of outside equity (Jensen and Meckling 1976), manifesting in poor acquisition decisions (Jensen 1986). For instance, Moeller, Schlingemann, and Stulz (2004) find that large public bidders generate lower announcement returns than smaller ones, which they attribute to greater agency costs at larger firms. Along similar lines, Masulis, Wang, and Xie (2007) show that poorly governed public bidders - as measured by their use of antitakeover provisions - exhibit lower returns than better governed bidders. Further, Harford (1999) shows that cash-rich public bidders are more likely to undertake value-destroying acquisitions.

In contrast, private firms exhibit higher levels of ownership by managers and higher levels of ownership concentration, aligning the interests of managers and shareholders and encouraging owners to more closely monitor management(Ang, Cole, and Lin 2000). For instance, 
Gao, Harford, and Li (2017), show that an average public firm in a sample similar to ours exhibits CEO ownership of $4.05 \%$ and ownership concentration by top 5 outside shareholders of $18.09 \%$; for private firms these statistics are $10.74 \%$ and $49.32 \%$, respectively. Sacchetto and Xiong (2018) quantify agency frictions for private and public firms using a structural estimation approach and find that large private firms face fewer agency problems than their public counterparts. If agency conflicts are one of the reasons behind poor performance of public acquirers, and if private firms face fewer such conflicts, we could expect private firms to generate greater efficiency gains from their acquisition activity. This leads to our main hypothesis.

H1: Private bidders generate greater acquisition-related efficiency gains than public bidders, ceteris paribus.

While the agency-based prediction is well-motivated theoretically, whether it holds true in the data remains an empirical question. This is because agency costs faced by public firms may be offset - or even outweighed - by benefits that are not available to private firms. Such benefits includeeasier access to capital, monitoring by analysts and the market for corporate control, learning from stock prices, and attracting better managerial talent. In addition, if concentrated shareholdings in private firms come at the expense of portfolio diversification, privatefirm managers may forgo profitable investment projects with high idiosyncratic risk. All of these circumstances may improve the investment opportunity set and decision-making at public firms vis-a-vis private companies. ${ }^{6}$

In light of this tension, we develop a secondary prediction designed to zero-in on the agency-based foundations of our main hypothesis. Since our premise is that a private firm

\footnotetext{
${ }^{6}$ Also, to the extent that private firms are not subject to the same capital market pressures emphasizing short-term profitability as public firms are, private firms are more likely to undertake deals that result in long-term value creation at the expense of immediate effects on earnings. At the same time, public firms may be coerced into deals that result in near-term improvements in profitability. If this is the case, our analysis focusing on the first three years following the deal could fail to detect greater operating performance changes for private bidders.
} 
is a (crude) proxy for a better-governed firm, we further conjecture that the private bidder effect should be concentrated among private bidders that exhibit governance characteristics traditionally associated with good corporate governance - and not present for private bidders whose governance arrangements look like those of public firms. Insider ownership and ownership concentration are variables that have been traditionally linked to the extent of agency problems. This is because insider ownership aligns the interests of managers with those of outside shareholders (Jensen and Meckling 1976), and because concentrated holdings make monitoring efforts worthwhile (Shleifer and Vishny 1986). More recent studies also suggest that provisions limiting shareholder power - such as antitakeover defences - can further entrench managers and result in agency costs (Gompers, Ishii, and Metrick 2003, Bebchuk, Cohen, and Ferrell 2008, Cremers and Ferrell 2014). Wetherefore put forward the following secondary hypothesis.

H2: The private bidder effect (if any) is driven by firms with strong internal governance characteristics (e.g., insider ownership is high, ownership concentration is high, use of takeover defences is low).

\subsection{Related studies}

Our paper joins a small but growing literature that studies private companies. Sheen (2019) and Asker, Farre-Mensa, and Ljungqvist (2015) find that private firms invest more and are more responsive to investment opportunities. On the other hand, Gilje and Taillard (2016) examine a unique dataset of U.S. natural gas producers and show that investment by private firms reacts less to changes in natural gas prices. Brav (2009) and Saunders and Steffen (2011) investigate the financial policies of private and public firms in the U.K. and find that private firms face higher costs of external finance. Michaely and Roberts (2012) study dividend policies of public and private firms in the U.K. and find that private firms smooth 
dividends significantlyless than public firms. Gao, Harford, and Li (2013) shows that private firms hold, on average, about half as much cash as public firms do.

In the voluminous M\&A literature, only two papers havetouched upon private acquirers. Bargeron, Schlingemann, Stulz, and Zutter (2008) investigate premiums paid in all-cash takeovers of U.S. public targets by private and public bidders from 1990 to 2005. They find that private equity bidders pay $63 \%$ lower premiums relative to public bidders, and that private operating companies (the focus of our paper) pay 14\% lower premiums relative to public firms. Maksimovic, Phillips, and Yang (2013) study a sample of acquisitions by U.S. manufacturing firms using plant-level data from the Census Bureau. They find that gains in total factor productivity are greater when the buyer is a public firm.

\section{Sample selection and basic results}

\subsection{The sample}

Our primary data source is the Capital IQ database. Starting from the late-1990s, Capital IQ provides data on U.S. firms' M\&A activity and financial information with a similar level of detail as provided by SDC Mergers and Acquisitions Database and Compustat for public firms. We start with U.S. public firms traded on the NYSE, Nasdaq, or Amex. A private firm is required not to have shares traded on any major stock exchange or OTC market. In the U.S., firms have to file financial reports with the Securities and Exchange Commission (SEC), if they have $\$ 10$ million or more in total assets and 500 or more shareholders $(2,000$ shareholders since April 2012), or if they list their securities with the SEC, such as public debt. Capital IQ collects private firms' financial data from the SEC through forms 10-K or $\mathrm{S}-1$. In our final sample, data for most private firms (96\%) come from 10-K reports, and the remainder (4\%) comes from S-1 filings. Most private firms in the sample are large or have access to public debt. Although they are not representative of a typical private firm, 
this makes them comparable to public firms in terms of size, disclosure requirements, and information availability.

We collect a sample of U.S. mergers and acquisitions from Capital IQ. M\&A data from Capital IQ, and in particular data on leveraged buyouts, have been used in a recent study by Axelson, Jenkinson, Stromberg, and Wesibach (2013). Following theliterature, we collect all completed transactions for the period 1997 to 2014 (to allow for 3 years worth of postacquisition performance data) in which the acquirer owns $100 \%$ of the shares of the target after the deal. Weexclude all deals with non-operating targets, with missing deal values, and where the bidder is a group of investors. Wefurther remove all regulated or financial bidders with SIC codes between 4900 and 4999 or between 6000 and 6999. Since our main variable of interest requires the operating performance before the deal to be available, we require all acquirers to have financial data in the year prior to the deal. Because a private bidder does not have publicly traded equity to offer, it is not surprising that most acquisitions by privatebidders are cash deals. In theinitial sample, morethan $90 \%$ of acquisitions by private bidders are all-cash deals. In contrast, about $40 \%$ of public bidders use all-stock payment or mixed offers. To obtain a sample where deals are most comparable between public and private acquirers, we exclude all non-cash deals. Excluding non-cash deals results in a final sample of 8,803 deals where 7,458 deals involve a public bidder and 1,345 deals a private bidder, although the sample size varies across tests due to the availability of the relevant outcome and control variables. ${ }^{7}$

Table 1 reports the distribution of the number and the aggregatevalue of the transactions measured in 2009 purchasing power through time. In total, public firms participate more than private firms as buyers of assets in mergers and acquisitions. Among all deals, $85 \%$ of

\footnotetext{
${ }^{7}$ We have compared Capital IQ M\&A data coverage with that of Thomson Reuters SDC. Applying the same sample selection criteria to both databases, we find that Capital IQ and SDC coverage of acquisitions by public bidders is very similar, but coverage of acquisitions by private bidders is significantly more comprehensive in Capital IQ.
} 
the deals involve a public bidder, with $15 \%$ deals involving a private bidder. ${ }^{8}$ In contrast, most target firms are private.

\subsection{Descriptive statistics}

We collect all financial performance measures and deal characteristics from Capital IQ. We focus on bidder and deal characteristics that both empirical and theoretical literature has found to be important. Panel A of Table 2 reports firm and deal characteristics for private acquirers and Panel B for public acquirers. ${ }^{9}$ Variable definitions are given in Table A.1 in the Appendix. The first two variables are total assets and operating income measured in CPI-adjusted 2009 dollars. It is not surprising that private bidders are smaller than their public counterparts in total assets and operating income. Wefind that private acquirers have higher leverage than public acquirers. Consistent with Gao, Harford, and Li (2013), we also find that public bidders hold, on average, more cash than private bidders do. Privatebidders tend to be younger firms and have fewer industry segments than public bidders. In addition, privatebidders have, on average, more tangible assets, investless in R\&D, and exhibit higher sales growth. Mean dollar value of deals measured in CPI-adjusted 2009 dollars is around $\$ 240$ million for both public and private bidders, and the median is around $\$ 30$ million. Given that deal values are comparable across public and private bidders, but public bidders

\footnotetext{
${ }^{8}$ The share of private bidders declines significantly over the early sample years, which we believe has to do with our sampling procedure. Since private bidders conduct almost exclusively cash-based acquisitions (they have no publicly-traded equity to offer), our sample is restricted to all-cash deals. The period of 19982000 was a period of rising equity valuations (sometimes referred to as the dot-com bubble), and public companies were increasingly using their stock to make acquisitions (e.g., Fig. 1 in Golubov, Petmezas, and Travlos 2016). In addition, pooling of interests merger accounting method was eliminated in 2001. Pooling of interests was popular among bidders as it resulted in no goodwill creation, and one of the conditions for the use pooling-of-interests accounting was that the deal is a stock-for-stock transaction. Hence, rich equity valuations and the availability of pooling-of-interests accounting contributed to a large portion of public firm M\&A deals being stock-financed. As stock-financed deals are excluded from our sample, this results in a greater fraction of private bidders in the early sample years as compared to later ones.

${ }^{9}$ It is interesting to also compare the characteristics of target firms. However, financial information for target firms is limited, because most targets are relatively small private firms that are not required to disclose to the SEC. Nevertheless, below we investigate target firm profitability in a subsample of deals.
} 
tend to be larger, relative deal size is greater for private bidders. The fraction of non-US targets is higher for public bidders, while the fraction of solicited deals is higher for private bidders. The fraction of targets from a two-digit SIC code other than that of the bidder is also somewhat higher for private bidders.

Finally, we compare our sample bidders to the full population of firms in Capital IQ (public and private, respectively). Table A.2 in the Appendix shows that, for both public and private companies, almost every firm characteristic is significantly different between bidders and the average firm. Typically, a bidder tends to be larger, older, has more industry segments, higher asset tangibility, and higher CAPEX than the average firm.

\subsection{Basic univariate comparisons across bidder types}

In this section, we examine post-acquisition operating performance changes for public and private bidders at the univariate level in the full sample. Our main measure of operating performance is return on assets (ROA): operating income before depreciation divided by total assets. Operating income captures the cashflows of the underlying business and is not affected by differences in capital structure, taxes, and depreciation policy. Scaling by total assets partially controls for divestitures and differences in growth and size. Broadly speaking, ROAcan be interpreted as measuring the efficiency with which the acquiring firms use aiven amount of assets, and changes in ROA can be interpreted as improvements in this efficiency. As an additional measure of efficiency, welook at asset turnover (ATO), defined as sales divided by total assets. This ratio captures the efficiency with which the firm is using its assets to generate revenue, and post-takeover changes measure improvements in productive asset utilization. We will also examine return on sales (ROS) in our later analysis.

Following Kaplan (1989) and Maksimovic, Phillips, and Yang (2013), we examine operating performance during the first three years after the deal. Specifically, we measure the change in the performance metric from the last year prior to deal completion (year -1$)$ to 
years one, two, and three following the consummation of the deal. We scale this change by the absolutevalue of pre-deal performance to facilitate interpretation and to make economic magnitude of the results readily apparent. This is consistent with the literature on operating performance improvements following leveraged buyouts (e.g., Kaplan 1989 and Guo, Hotchkiss, and Song 2011). ${ }^{10}$ We exclude year o (the year of completion) as those figures are difficult to interpret as pre- or post-deal performance. Furthermore, accounting measures in year o may be abnormal due to deal-related fees and asset write-ups. In all subsequent tests we trim the sample by removing the $5^{\text {th }}$ and $95^{\text {th }}$ percentiles of the dependent variable to reduce the influence of outliers.

The first panel of Table 3 reports raw (unadjusted), industry-adjusted, and control-firmadjusted mean percentage changes in ROA and ATO for private bidders. Industry-adjusted and control-firm-adjusted measures attempt to provide a measure of abnormal performance changes. Industry-adjusted performance changes are net of the median performance change of the bidder's 2-digit SIC industry over the same period (bidding firms are purged from the computation of industry medians). Control-firm-adjusted performance changes are net of the contemporaneous performance change of a control firm chosen in year -1 . The control firm is of the same listing status, comes from the same 2-digit SIC industry, and has the level of ROA in year -1 closest to that of the bidder (this is prior-performance-matching as recommended by Barber and Lyon (1996)). During the first three years, ROAs of private bidders improve by $7.96 \%, 7.44 \%$, and $6.92 \%$, all significantly different from zero. Turning to ATO, the improvements are $3.48 \%, 4.39 \%$, and $5.14 \%$ in years one, two, and three, respectively. Using industry-adjusted and control-firm adjusted performance improvements, we continue to find that private bidders experience positive changes in ROA and ATO and the magnitudes are similar to the unadjusted values.

\footnotetext{
${ }^{10}$ Our conclusions are the same when using percentage point (unscaled) changes. See Table A.5 in the Appendix.
} 
The second panel of Table 3 reports the same outcomes for public bidders. On average, publicbidders experience negative changesin ROAof $-0.77 \%,-1.31 \%$, and $-2.07 \%$ inyears $+1,+2,+3$ on an unadjusted basis, respectively. The same pattern is observed for ATO, where mean percentage changes are $-1.61 \%,-2.31 \%$, and $-2.29 \%$, in years one, two, and three, respectively. All of the changes are also significantly different from zero. Once again, industry-adjusting or control-firm adjusting performance improvements does not change the picture in most cases: on average, public bidders experience zero-to-negative changes in ROA and ATO following mergers. The only exception is the control-firm-adjusted change in ATO, which becomes positive in years two and three. The bottom panel of Table 3 reports differences between public and private firm changes in ROA and ATO. These differences are statistically significant across all years and performance measures. Overall, private bidders exhibit incremental $3-9 \%$ changes in ROA and ATO. ${ }^{11}$

We also investigate whether private firms exhibit higher changes in ROA and ATO in general - regardless of acquisition activity. However, we do not find this. These results are reported in the Appendix. For this analysis, we focus on the entire population of private firms in Capital IQ and use both the full sample and a matched sample of public firms. Following the literature such as Gao, Harford, and Li (2013) and Asker, Farre-Mensa, and Ljungqvist (2015), we match private and public firms with replacement based on size and industry. For each private firm, we select a matched public firm closest in size (total assets) from the same 2-digit SIC industry and year. If no match is found, we discard the observation from the sample. Wethen compare changes in operating performance between private and public firms one, two, and three years in the future. Table A.3 presents these results. With the exception of a negative difference in the change in ROA in year +3 relative to the overall population of public firms, private firms generally exhibit the same evolution of ROA and

\footnotetext{
${ }^{11}$ We also perform our tests (full sample comparisons and the matching estimator) using median changes in ROA and ATO. Our conclusions are unchanged. Please see Table A.6 in the Appendix.
} 
ATO. Hence, our results on superior operating performance changes for private bidders are likely attributable to their acquisitions.

While the initial evidence is consistent with our hypothesis $H 1$ that private bidders undertake better acquisitions, this full sample comparison is naive because it ignores the fact that being public or private is, likely, an endogenous decision. The listing status can be correlated with a variety of characteristics, thus affecting the evolution of firms' operating performance. Of particular concern is a variable that is positively correlated with the propensity to stay private and, at the same time, positively affects post-takeover operating performance changes. ${ }^{12}$ In the next section we describe our approach to dealing with this identification concern and present our main results.

\section{Main results}

\subsection{Empirical setup}

Werely on state-of-the-art matching techniques as our main research design. For robustness we also consider an instrumental-variable (IV) approach. ${ }^{13}$ The matching technique we use is a variable ratio ( $k: 1)$ nearest neighbor matching (with replacement), whereby the nearest neighbors are identified based on a propensity score. Specifically, for each deal in the private bidder sample, we select up to 5 deals from the public bidder sample that are in the same industry, same year, and closest in the propensity of the bidder in question to be private. Wethen compare the outcomes for each private bidder deal to the outcomes of its matched

\footnotetext{
${ }^{12}$ Note that if the omitted variable correlated with the propensity to stay private negatively affects posttakeover performance, then this would bias our results downward, working against our finding of a positive private bidder effect. The typical narrative, whereby high quality firms/assets select into public status, fits this description - to the extent that asset quality is positively related to performance changes following takeovers, public firms would be expected to do better than private firms.

${ }^{13}$ Another potential (imperfect) solution could be to use within-firm variation in public/private status. Unfortunately, there is not enough firms in our sample that change listing status and conduct acquisitions both before and after the change.
} 
public bidder deal(s) only. Weperform this comparison on both univariate and multivariate basis. The latter is known as further regression adjustment (or "double robustness") in the matching literature (see a review by Stuart 2010). ${ }^{14}$

We start with a probit regression where the private bidder indicator is the dependent variable and the explanatory variables are bidder characteristics as of year -1 relative to the deal. Specifically, we use the natural logarithm of revenue as a measure of size, the level of ROA and the change in ROA between year -1 and -2 as measures of prior performance, natural logarithm of firm age as a proxy for life cycle, as well as cash holdings, leverage, capital expenditures, assettangibility, sales growth, number of segments, and R\&Dintensity. These variables are included because all of them exhibit statistically significant differences between public and private bidders as shown in Table 2. Industry (2-digit SIC) and year fixed effects arealso included, because we select nearest neighbours conditional on the same industry and year and want the propensity score to be a function of residual differences in the covariates. We use the estimates from this probit regression to calculate bidding firms' propensity scores (i.e., the probability that the bidder is private, conditional on the covariates) and then match each private bidder transaction to up to 5 public bidder deals from the same industry and year by minimizing the absolute value of the differences in their propensity scores. The goal is to compare private bidders to public bidders from the same industry and year that were just as likely to be private given their observable characteristics.

Table 4 reports the results of our matching procedure. First, Panel A reports the propensity score estimation results. Most variables in the propensity score model are statistically significant predictors of a bidder's listing status. Smaller, better performing, and younger

\footnotetext{
${ }^{14}$ In terms of implementation, this estimator is obtained by regressing the outcome variable on the private bidder indicator (with or without controls) and a fixed effect that uniquely identifies each private bidder deal and its matched public bidder deal(s). Given that we use variable ratio matching (there can be between 1 and 5 public bidder control deals depending on availability), the estimation is weighted such that each private bidder deal receives the weight of one, and each public bidder deal receives the weight of $1 / n$, where $n$ is the number of public bidder control deals for a given private bidder deal.
} 
bidders are more likely to be private. Private bidders also hold less cash, are more levered, have fewer tangible assets and fewer segments. This mirrors the univariate differences observed in Table 2 (with the exception of tangibility, where the univariate difference was of the opposite sign). The pseudo- $R^{2}$ of the propensity score model is reasonably high at 34.4\%. Panel A further reports diagnostics from our matching procedure, namely, mean differences in characteristics entering the propensity score estimation between private bidders and their propensity-score matched public counterparts. Only one covariate difference (prior profitability, $\mathrm{ROA}(-1)$ ) is significantly different from zero, indicating that our matching procedure successfully eliminates virtually all observable differences that exist prior to matching. ${ }^{15}$

Panel B of Table 4 reports the distribution of the number of matches we obtain for each private bidder deal. In the $81.87 \%$ of cases we obtain 5 matches. Overall, our post-PSM sample contains 899 deals by private bidders and 4,080 deals by public bidders.

\subsection{Baseline matching estimates}

Table 5 reports the results of our main tests of hypothesis $H 1$. Panel A reports the univariate difference in $\Delta \mathrm{ROA}$ and $\Delta \mathrm{ATO}$ around the acquisition between private bidders and their matched public bidders. We find that private bidders improve their ROA and ATO significantly more than their matched public bidders. The differences in operating performance changes between public and private bidders are all positive and statitically significant at the $1 \%$ level. Private bidders experience incremental $\Delta$ ROA of $7-11 \%$ and incremental $\Delta$ ATO of 5-6\%. These magnitudes are comparable to those in the full sample analysis. It appears that selection on observable characteristics does not bias our results significantly.

\footnotetext{
${ }^{15}$ Note that testing for statistically significant differences as a matching diagnostic is too high a bar in large samples, because economically small differences can be precisely estimated when the number of observations is large. The matching diagnostic prescribed in the matching literature is the standardized mean difference (standardized by the standard deviation of the covariate in the treated population (private bidders)), which should be no greater than 0.25 (Stuart (2010)). This is the case for all of our covariates, including $\operatorname{ROA}(-1)$.
} 
Panel B of Table 5 performs further regression adjustment of these estimates by controlling for prior performance (the level of and the change in ROA prior to the deal), size ( $\log ($ revenue $)$ ), as well as additional bidder and deal characteristics found important by prior literature, namely a dummy for private targets, relative size of the deal (deal value to total assets) and its square, age of the bidder (in logs) and its acquisition experience (deal order), and dummies for hostile deals, solicited deals, diversifying deals, and cross-border deals. Stack fixed effects ensure that each private bidder is compared only to its own set of matched public bidders (as opposed to all public bidders). The coefficient on PrivateBidder is of interest.

The estimation results confirm that on average private acquiring firms experience greater changes in profitability than public acquiring firms in terms of ROA. The coefficient on PrivateBidder, the indicator for whether the bidder is private, is positive and significant at the $1 \%$ level for all three post-takeover years. Private acquirers realize an incremental $7.3 \%$ increase in ROA during the year after the acquisition, 9.5\% two years after the acquisition, and $6.7 \%$ threeyears after the acquisition compared to public acquirers. Wealso find that the coefficients on $\operatorname{ROA}(-1)$ and $\Delta \operatorname{ROA}(-2,-1)$ are negative and significant in all columns, implying a negative association between the bidder's pre-deal operating performance and subsequent changes.

Regression estimates for $\Delta$ ATO are similar. The specification is the same except that controlsfor prior performance measure prior level and growth in ATOinstead of ROA.Again, we find that private acquirers realize greater improvements in ATO than public acquirers. The coefficients on PrivateBidder are positive and statistically significant at the $1 \%$ level for all years. The incremental improvements in ATO are on the order of 5.2-6.3\%. The coefficients on $\operatorname{ATO}(-1)$ are negative and significant in all specifications, consistent with the regression estimates using ROA as the performance measure. Across both ROA and ATO regressions, the coefficient on relative size is negative, suggesting that large deals are 
associated with lower changes in profitability, while the coefficient on deal order (experience) is generally positive and significant.

Overall, there is strong evidence that acquiring firm listing status is associated with posttakeover performance. This result holds after controlling for numerous potential confounding effects, such as differences in acquirer size, prior performance, growth opportunities (age) and acquisition experience, relative deal size, target type (private vs public target), and various deal types. So far our results are consistent with the notion that private bidders make better acquisition decisions, as predicted by hypothesis $H 1$.

\subsection{Instrumental variable approach}

It is possible that, despite the matching process, there remains an unobserved characteristic that is positively correlated with both privatefirm status and operating performance changes following takeovers. To address this concern, we employ an instrumental variable (IV) approach as an alternative to our matching design. Here we borrow from Asker, Farre-Mensa, and Ljungqvist (2015), who compare investment behavior of public and private firms and instrument listing status with venture capital (VC) availability in the firm's headquarter state 2 years after foundation. ${ }^{16}$ Specifically, the variable VCsupply is the number of firms receiving first-round VCfunding in the firm's headquarter state two years after the firm was founded, scaled by the number of firms in the state that were less than three years old at that time (VC data is from VentureExpert, and the number of firms less than three years old is from the Longitudinal Business Database of the U.S. Census Bureau). The instrument varies by state-year, and the intuition behind its relevance is straightforward: firms are more likely to have gone public at some point if they have received VC backing in their early years. This is because VC investors need an exit event to realize the value of their

\footnotetext{
${ }^{16}$ We thank John Asker, Joan Farre-Mensa, and Alexander Ljungqvist for making their instrument available to us.
} 
investment. Therefore, VC availability in the firm's geography two years after its foundation (typical firm age in first-round VC deals) should be positively associated with the likelihood that the firm has early VC investors, which, in turn, increases the probability of an eventual IPO. The exclusion criterion (the instrument must not affect the outcome variable of interest other than through its effect on the endogenous variable) should be satisfied by the virtue of time separation. That is, even if firms or VC investors were attracted to the particular geography by favorable economic conditions, many years have passed from that time until the measurement of our outcome variables, rendering any such correlationless relevant. The median age of our private firms at the time of the deal is 20 years, and the median for public firms is 30 years. Nevertheless, to the extent that the economic factors driving regional VCintensity are persistent, causing our instrument to be correlated with current economic conditions, the exclusion restriction will be violated. ${ }^{17}$

Given that our main endogenous variable is binary, we use a three-step approach described in Angrist and Pischke (2009) and used, for example, in Adams, Almeida, and Ferreira (2009). In the first step we estimate a probit model of a firm's listing status as a function of the instrument and other covariates. Wethen use the predicted probability from this probit regression as an instrument for the firm's listing status in the usual (linear) 2SLS model. The benefit of this approach is that it avoids the "forbidden regression" problem while allowing for a non-linear functional form in the association between early years VC availability and listing status (for a potential gain in efficiency).

Table 6 presents the results of our IV analysis (only the coefficients of interest are shown;

\footnotetext{
${ }^{17}$ To assess the severity of this concern, we examine the persistence of VC intensity over time. In particular, we sort states into quintiles based on their VC intensity in a given year, and then track the fraction of states that are still in the same quintile many years later. The results indicate that persistence in VC intensity at the state level is not particularly strong and decays substantially over time. For instance, while $65.25 \%$ of the states falling into the bottom quintile of $\mathrm{VC}$ intensity are still in the bottom quintile the following year, this fraction drops to $47 \%$ at $t+10$, to $41.6 \%$ at $t+20$, and $31.46 \%$ at $t+30$. Twenty and thirty year marks are of interest given that this is the average age of our private and public bidders, respectively. Persistence is somewhat stronger at the top of the distribution, with the one year out fraction of $65 \%$ falling to $55.9 \%$, $52.35 \%$, and $47.14 \%$ in years 10,20 , and 30 , respectively.
} 
other covariates are identical to those used in our main regressions above). Panel A reports the first step probit model estimation. The relevance of venture capital availability at founding for a firm's listing status is evident: the $V$ Csupply variable is a strong negative predictor of a firm's private status many years later. The coefficient is statistically significant at the $1 \%$ level in all but the last specification (where it is significant at the $5 \%$ level). We obtain the predicted probability from this regression and use it as an instrument in a 2SLS model. Panel B reports the first stage, showing that the predicted probability of being private is a strong positive predictor for being a private firm. The F-test for the excluded instrument is significantly above 10, which is the recommended cut-off value for the case of one endogenous variable and one instrument (Staiger and Stock 1997). Panel C reports the second-stage estimation results. We find that the instrumented private bidder indicator continues to be positive and significant across all specifications. The fact that the effect is robust to instrumentation suggests that, subject to the exclusion restriction being satisfied, the private bidder effect is not picking up unobserved characteristics that are not a direct outcome of being a public versus a private firm. The magnitudes of the private bidder effect we obtain in this alternative identification approach are greater than those in our baseline matching approach. Toremain conservative, we will usethe matching approach in the remainder of our tests.

In the following sections we examine the hypothesized agency channel as well as the mechanism behind the private bidder effect. In other words, we ask why private bidders perform better than public bidders, and how they achieve that. In addition, we attempt to rule out possible alternative or mechanical explanations. 


\section{The agency cost channel}

Our results suggest that operating performance changes around acquisition deals are greater when the bidder is private than when the bidder is public. What is the reason for this outperformance? We have argued above that public ownership comes with greater agency conflicts relative to private ownership. We now investigate directly whether agency costs are behind the private bidder effect. In particular, we test hypothesis $H 2$, which predicts that the private bidder effect is driven by private bidders with strong internal governance characteristics, such as high insider ownership, high ownership concentration, and few limits to shareholder power.

While firm-level data on governance arrangements in private firms are scarce, we are able to obtain three such variables, namely, CEO ownership, ownership concentration by top 1 outside shareholder, and a takeover defence score. ${ }^{18}$ The latter variable comes from Capital IQ, while data on CEO ownership and ownership concentration comefrom Gaoand Li(2015) and Gao, Harford, and $\mathrm{Li}$ (2017), which we further hand-collect for the most recent sample years. ${ }^{19}$

We begin by summarizing the four governance variables for public and private firms. For the sake of exposition these statistics are presented in Table A.4 of the Appendix. As expected, private firms exhibit significantly higher levels of CEO ownership (mean of 0.092 vs. 0.043), and ownership concentration by top 1 outside shareholder (mean of 0.462 vs. 0.112). In addition, the average takeover defence score for private firms is significantly lower than for public firms ( $0.237 \mathrm{vs}$. 0.320 ), indicating that private firms use fewer provisions

\footnotetext{
${ }^{18}$ Capital IQ covers 24 unique antitakeover and corporate governance provisions, from which it constructs a takeover defence score. In addition to standard antitakeover provisions such as poison pills and classified boards, this index captures such limitations/enhancements of shareholder rights as cumulative voting for board seats, causes for director removal, and limits to amend the corporate charter and bylaws, among others. The score is a number between 0 and 1 , where a higher score indicates greater limitations to shareholder control. This takeover defence score is similar to corporate governance indices computed in Gompers, Ishii, and Metrick (2003) and Masulis, Wang, and Xie (2007).

${ }^{19}$ We would like to thank Huasheng Gao for kindly sharing these variables with us.
} 
limiting shareholder rights. Overall, these statistics are consistent with private firms having better incentive alignment between managers and shareholders, as well as monitoring by shareholders. $\mathrm{H} 2$ predicts that the private bidder effect is most pronounced for private bidders characterized by stronger governance arrangements. To test this hypothesis, we split our private bidders into three subsets according to the level (high, medium, and low using tercile points of the distribution) of CEO ownership, ownership concentration by top 1 and top 5 outside shareholders, and takeover defense score. Wethen run subsample regressions, whereby we estimate the private bidder effect separately for each subset of private bidders. ${ }^{20}$ Table7presents the results. Only the coefficient of interest is shown; regression specifications are the same as those in Table 5.

Panel A uses CEO Ownership as our first governance proxy. As predicted by the agency channel, the private bidder effect is concentrated in firms with high and medium CEO ownership. There is no positive private bidder effect when comparing public bidders to low CEO ownership private bidders. Panel B uses the concentration of ownership by the top 1 outside shareholder as our second governance characteristic. Once again, we find that the privatebidder effect is driven by firmsinthetop tercileof ownership concentration byoutside shareholders. This is despite a significant reduction in sample size in this panel (ownership concentration is available only after 2003). In Panel C we use the takeover defence score as our final internal governance proxy. The private bidder effect is driven by private firms with the lowest and medium level of takeover defence use. Overall, our results support $H 2$ : the private bidder effect is driven by private bidders that exhibit characteristics traditionally associated with low agency costs.

A question that still remains, though, is how exactly do private bidders achieve superior operating performance around acquisition events. In other words, while agency costs is the

\footnotetext{
${ }^{20}$ Note that we do not split the control group of public bidders associated with each private bidder. Our goal is to examine how different types of private bidders compare to their public bidder matches.
} 
channel behind the private bidder effect, what is the mechanism behind it? While we are limited in terms of data availability, we perform three tests designed to shed light on this question.

First, we consider whether private bidders are more likely to generate production cost efficiencies, as captured by changes in the ratio of cost of goods sold (COGS) to total assets. Second, we assess whether private bidders are more likely to find overhead savings, as proxied by changes in the ratio of selling, general, and administrative expenses (SG\&A) to total assets. Third, we test whether private bidders are more likely to identify investment efficiencies, as proxied by the change in the ratio of capital expenditures (CAPEX) to total assets.

The results of this analysis are reported in Table 8. Private bidders experience greater reductions in SG\&A expenses, but no significant differences in changes in COGS. Private bidders also experience greater reductions in CAPEX. Thus, it appears that the mechanism behind superior operating performance improvements by private bidders is better containment of overhead costs and greater investment efficiency. Overall, these mechanisms tie well with the agency cost channel that we document. We now consider whether alternative explanations can account for the private bidder effect.

\section{Alternative explanations}

\subsection{Do private bidders buy more profitable targets?}

So far we find higher changes in ROA and ATO for private bidders around takeover events. One possible explanation is that private acquirers simply pick targets with higher levels of, or growth rates in, operating performance. Note that we compare pre-deal operating results of the bidder with the post-deal operating results of the combined firm assets. Toinvestigate this concern, we examine target firms' pre-deal performance. However, this analysis is limited 
to a subsample of target firms with financial information available from Capital IQ, because most target firms are private and small. As the overlap between the post-PSM sample and the sample for which target firm financials are available is too small to conduct meaningful tests, the analysis in this subsection is performed on the full sample.

We measure the level as well as the percentage change of the target firm's ROA and ATO in the last fiscal year prior to deal completion (relative to two years prior in the case of changes). Table 9 reports target's pre-deal performance. There are no discernible differences in levels of ROA and ATO (Panel A) and growth rates in ROA and ATO (Panel B) of the targets of public and private bidders.

Another wayto assess whether targets of privatebidders are more profitable is to examine prices paid for those assets. If targets acquired by private bidders are more profitable, one would expect higher prices paid for those assets (holding risk constant). Panel C examines mean and median transaction multiples paid bypublic and private bidders. Weusedealvalue to total assets, deal value to sales, and deal value to operating income before depreciation. These multiples approximate price-to-book, EV/Sales and EV/EBITDA valuation multiples. We find that private bidders consistently pay lower prices for their targets: all transaction multiples are significantly lower for targets acquired by private firms. Panel D repeats this analysis in a regression framework with industry and year fixed effects to control for differences in the composition of deals in terms of industry and timing. Once again, we find that private bidders are paying lower transaction multiples. This result confirms the findings of Bargeron, Schlingemann, Stulz, and Zutter (2008) who find that private bidders pay lower bid premiums for comparable public targets. Overall, there is no evidence that targets of private bidders are more profitable, ruling this out as a possible explanation for better post-takeover performance of private firms.

Finally, Panel E conducts regression analysis of operating performance changes similar to that reported in Table 5 on a subsample of deals with target firm financials available. 
The difference is that we use the weighted-average performance of the bidder and the target in year $t-1$ in the computation of the dependent variable. ${ }^{21}$ Only the coefficient of interest is reported. The sample size declines significantly to just over 1,000 observations (with only about 100 acquisitions by private firms), suggesting that power may be an issue. Nevertheless, we continue to find a positive and significant private bidder effect in 5 out of 6 specifications.

\subsection{Merger accounting}

Second potential explanation that we address has to do with merger accounting. Under U.S. Generally Accepted Accounting Principles (GAAP), the bidder has to account for the entire purchase price on its balance sheet. Any value in excess of the (stepped up) value of identifiable assets is recognized as goodwill. ${ }^{22}$ If public bidders pay higher prices (as we have shown above), then more accounting goodwill is created, resulting in a higher accounting asset base for the combined firm. Since we measure ROA as the ratio of operating income to total assets, this can potentially explain why public acquirers have smaller post-deal ROA and the associated changes from before to after the deal. To mitigate this measurement concern, we use return on sales (ROS), as in the Custodio (2014) study of the diversification discount. Similar to ROA, we measure the annual percentage changes in ROS in the first three years following deal completion (years $+1,+2,+3$ ) relative to the most recent fiscal year prior to the deal. Panel A of Table 10 reports univariate comparisons between private bidders and matched public bidders, and Panel B reports the results of further regression adjustment. Our results continue to hold. Univariate differences in ROS changes between private and public bidders are all positive statistically significant. Similarly, the coefficients on the PrivateBidder indicator in Panel B are positive and significant at the $5 \%$ level for

\footnotetext{
${ }^{21}$ Given that we use the full (pre-PSM) sample in this analysis, stack fixed effects are replaced with industry and year fixed effects.

${ }^{22}$ This is also the case under International Financial Reporting Standards (IFRS).
} 
all windows. The magnitude of the effect is comparable to that in prior analysis using ROA and ATO, with 3-4\% greater changes in profit margins for private bidders. Therefore, merger accounting effects cannot be the explanation behind better ROA and ATO changes for private bidders.

\subsection{Access to capital}

Another reason for better observed performance of private bidders could be the fact that they are more financially constrained. Specifically, if private bidders can finance only their best acquisition opportunity, whereas less constrained public bidders are able to finance more marginal deals, this would bring down the average post-takeover performance changes of public firms. Note that this would still imply that private firms make acquisitions with greater efficiency gains, but agency conflicts we allude to are not the reason behind it. Preliminary investigation of the data suggests that this is a valid concern: private bidders in our sample conduct an average of three acquisitions, while public firms conduct an average of five deals.

To formally test this explanation, we proxy for financing constraints with three different variables. First, we employ the SA index from Hadlock and Pierce (2010), who show that it performs better than the Kaplan-Zingales index (Lamont, Polk, and Saa-Requejo 2001) and the Whited-Wu index (Whited and Wu 2006). ${ }^{23}$ The SA index is based on firm characteristics that predict actual qualitative assessments by management of their firms' ability to access capital. Hadlock and Pierce (2010) show that firm size, size-squared, age, leverage, and free cash flow are consistently associated with financing constraints. While leverage and free cash flow do incrementally predict the level of financing constraints (positively and negatively, respectively), Hadlock and Pierce (2010) choose to avoid these arguably more endogenous

\footnotetext{
${ }^{23}$ Besides, the computation of the Kaplan-Zingales and Whited-Wu indices require numerous financial variables that are often missing for private firms.
} 
variables in the construction of their index. We therefore use leverage and free cash flow separately as additional indicators of financing constraints. According to Hadlock and Pierce (2010), high levels of SA index, high leverage, and low free cash flow are symptomatic of high levels of financing constraints. If limited access to capital is the reason why private firms do better deals, we should find that the private bidder effect is driven by financially constrained private bidders.

Table 11 presents the results of our subsample analysis, whereby private bidders are split into low, medium, and high financing constraints based on tercile points of the distribution. Onceagain, wereport only the coefficient of interest; all controlvariables areincluded. Panel A uses the SA index of Hadlock and Pierce (2010) as our first proxy for financing constraints. Interestingly, the private bidder effect is concentrated in private bidders with medium and low levels of SA index - opposite to what the access to capital explanation predicts. Panels $\mathrm{B}$ and $\mathrm{C}$ use free cash flow and leverage, respectively, as two additional proxies for financing constraints. Once again, we find results inconsistent with access to capital explanation of the private bidder effect: it is driven by private bidders with medium and high free cash flow, and with medium and low leverage (less constrained private bidders). Overall, it appears that more selective deal making as a result of greater challenges in accessing capital cannot explain the private bidder effect.

\subsection{Subsequent listing and organizational form}

Finally, successful acquirers may change their listing status after the acquisition. For example, private acquirers may choose to go public after their acquisitions. If so, greater performance improvements of private acquirers may be due to the IPO and the infusion of capital to fund growth and not from their acquisitions. In the sample, only 214 (15.9\%) private acquirers go public within 3 years after the deal, and only 36 (0.4\%) public acquirers go private within 3 years after the deal. We eliminate these bidders from the sample 
and rerun the regression adjustment tests. The results are shown in Panel A of Table 12. The coefficients on PrivateBidder remain positive, with magnitudes and significancelevels similar to those in prior analysis.

We further examine the organizational form of private bidders in our sample. First, we distinguish between independent private firms and those whose ultimate parent is a listed firm. We find that $23.8 \%$ of private bidders in our sample have public firms as their ultimate parents. We then examine whether these bidders perform any differently to independent private firms (one prediction could be that private firms whose ultimate parents are public may suffer from similar agency conflicts as their parents). Panel B of Table 12 reports the subsample analysis. With the exception of the change in ATO in years +1 and +2 , the private bidder effect is observed only for independent private firms and not for private firms whose ultimate parent is public.

Finally, we also investigate whether the private bidder effect is driven by the private equity ownership model. Capital IQ provides information on whether the firm has received private equity sponsorship at any point in time. Similar to all of our tests above, we split private bidders into those that have never received private equity investment and those that did and perform subsample tests. Panel C of Table 12 reports the estimation results. While the subsample of non-PE backed private firms is small, we find that the private bidder effect is generally present in both subsamples, suggesting that the effect is common to the private ownership model more broadly.

\section{Conclusion}

Using a dataset covering both public and large private U.S. firms, we examine the effect of public versus private ownership on post-merger operating performance improvements. In particular, we test the hypothesis that acquisitions by private firms generate greater 
efficiency gains due to lower agency costs in private firms. Besides, private acquirers are of great interest in their own right, since virtually all existing evidence on acquirer performance is limited to public bidders.

We find that, on average, private acquirers experience greater operating performance changes following takeovers. Consistent with the agency cost channel, the effect is driven by private bidders with high CEO ownership and ownership concentration, and fewer limits to shareholder rights. We further examine the sources of superior operating performance changes in acquisitions by private bidders and find that they stem from better containing overhead costs and capital expenditures.

Overall, our evidence supports the view that private firms face fewer agency problems and make better investment decisions as a result. One limitation of our analysis is that we are not able to differentiate between various types of private firm ownership (e.g. familyowned versus venture-capital-controlled). The heterogeneity in governance arrangements across different types of private firms is an interesting topic for future research. 


\section{References}

Adams, R., H. Almeida, and D. Ferreira, 2009, "Understanding the relationship between founder-CEOs and firm performance," Journal of Empirical Finance, 16(1), 136 - 150.

Ang, J. S., R. A. Cole, and J. W. Lin, 2000, “Agency costs and ownership structure,” The Journal of Finance, 55(1), 81-106.

Angrist, J. D., and J.-S. Pischke, 2009, Mostly harmless econometrics. Princeton University Press.

Asker, J., J. Farre-Mensa, and A. Ljungqvist, 2015, “Corporate investment and stock market listing: A puzzle?," Review of Financial Studies, 28(2), 342-390.

Axelson, U., T. Jenkinson, P. Stromberg, and M. S. Wesibach, 2013, "Borrow cheap, buy high? The determinants of leverage and pricing in buyouts," The Journal of Finance, 68(6), 2223-2267.

Barber, B., and J. D. Lyon, 1996, “Detecting abnormal operating performance: The empirical power and specification of test statistics," Journal of Financial Economics, 41(3), 359-399.

Bargeron, L. L., F. P. Schlingemann, R. M. Stulz, and C. J. Zutter, 2008, "Why do private acquirers pay so little compared to public acquirers?," Journal of Financial Economics, 89(3), 375-390.

Bebchuk, L., A. Cohen, and A. Ferrell, 2008, "What matters in corporate governance?," The Review of Financial Studies, 22(2), 783-827.

Bernstein, S., 2015, "Does going public affect innovation?," The Journal of Finance, 70(4), $1365^{-1403 .}$ 
Betton, S., B. E. Eckbo, and K. S. Thorburn, 2008, “Corporate takeovers," in Handbook of Empirical Corporate Finance, ed. by B. E. Eckbo. Elsevier, Amsterdam, Handbooks in Finance, pp. $291-429$.

Brav, O., 2009, "Access to capital, capital structure, and the funding of the firm," The Journal of Finance, 64(1), 263-308.

Cremers, M., and A. Ferrell, 2014, "Thirty years of shareholder rights and firm value," The Journal of Finance, 69(3), 1167-1196.

Custodio, C., 2014, "Mergers and acquisitions accounting and the diversification discount," The Journal of Finance, 69(1), 219-240.

Fuller, K., J. Netter, and M. Stegemoller, 2002, "What do returns to acquiring firms tell us? Evidence from firms that make many acquisitions," The Journal of Finance, 57(4), $1763-1793$.

Gao, H., J. Harford, and K. Li, 2013, “Determinants of corporate cash policy: Insights from private firms," Journal of Financial Economics, 109(3), 623-639.

_ 2017, "CEOturnover-peformance sensitivities in private firms," Journal of Financial and Quantitative Analysis, 52(2),583-611.

Gao, H., and K. Li, 2015, "A comparison of CEO pay-performance sensitivity in privatelyheld and public firms," Journal of Corporate Finance, 35, 370-388.

Ghosh, A., 2001, "Does operating performance really improve following corporate acquisitions?," Journal of Corporate Finance, 7(2), 151- 178.

Gilje, E., and J. Taillard, 2016, "Do public firms invest differently than private firms? Taking cues from the natural gas industry," The Journal of Finance, 71(4), 1733-1778. 
Golubov, A., D. Petmezas, and N. G. Travlos, 2016, “Do stock-financed acquisitions destroy value? New methods and evidence," Review of Finance, 20(1), 161-200.

Golubov, A., A. Yawson, and H. Zhang, 2015, "Extraordinary acquirers," Journal of Financial Economics, 116(2), $314-330$.

Gompers, P., J. Ishii, and A. Metrick, 2003, “Corporate governance and equity prices,” The Quarterly Journal of Economics, 118(1), 107-155.

Guo, S., E. S. Hotchkiss, and W. Song, 2011, “Do buyouts (still) create value?," The Journal of Finance, 66(2), 479-517.

Hadlock, C. J., and J. R. Pierce, 2010, "New evidence on measuring financial constraints: moving beyond the KZ index," Review of Financial Studies, 23(5), 1909-1940.

Harford, J., 1999, “Corporate cash reserves and acquisitions,” The Journal of Finance, 54(6), 1969-1997.

Healy, P. M., K. G. Palepu, and R. S. Ruback, 1992, “Does corporate performance improve after mergers?," Journal of Financial Economics, 31(2), 135 - 175.

Heron, R., and E. Lie, 2002, "Operating performance and the method of payment in takeovers," Journal of Financial and Quantitative Analysis, 37(1), 137-155.

Jensen, M. C., 1986, “Agency costs of free cash flow, corporate finance, and takeovers," American Economic Review, 76(2), 323-329.

Jensen, M. C., and W. H. Meckling, 1976, "Theory of the firm: Managerial behavior, agency costs and ownership structure," Journal of Financial Economics, 3(4), 305-360.

Kaplan, S., 1989, "The effects of management buyouts on operating performance and value," Journal of Financial Economics, 24(2), 217-254. 
Lamont, O., C. Polk, and J. Saa-Requejo, 2001, "Financial constraints and stock returns," Review of Financial Studies, 14(2), 529-554.

Maksimovic, V., G. Phillips, and L. Yang, 2013, "Public and private merger waves," The Journal of Finance, 68(5), 2177-2217.

Masulis, R. W., C. Wang, and F. Xie, 2007, "Corporate governance and acquirer returns,” The Journal of Finance, 62(4), 1851-1889.

Michaely, R., and M. R. Roberts, 2012, “Corporate dividend policies: Lessons from private firms," Review of Financial Studies, 25(3), 711-746.

Moeller, S. B., F. P. Schlingemann, and R. M. Stulz, 2004, "Firm size and the gains from acquisitions," Journal of Financial Economics, 73(2), 201-228.

_ 2005, "Wealth destruction on a massive scale? A study of acquiring-firm returns in the recent merger wave," The Journal of Finance, 60(2), 757-782.

Mulherin, J. H., J. M. Netter, and A. B. Poulsen, 2017, "The evidence on mergers and acquisitions: a historical and modern report," in The Handbook of the Economics of Corporate Governance, ed. by B. E. Hermalin, and M. S. Weisbach. Elsevier, Amsterdam, Handbooks in Economics, pp. 235 - 290.

Netter, J., M. Stegemoller, and M. B. Wintoki, 2011, "Implications of data screens on merger and acquisition analysis: A large sample study of mergers and acquisitions from 1992 to 2009," The Review of Financial Studies, 24(7), 2316-2357.

Sacchetto, S., and N. Xiong, 2018, "How costly are external finance and agency for private firms?,"Working paper, University of Surrey and IESE Business School.

Saunders, A., and S. Steffen, 2011, "The costs of being private: Evidence from the loan market," Review of Financial Studies, 24(12), 4091-4122. 
Sheen, A., 2019, "Do public and private firms behave differently? An examination of investment in the chemical industry," Journal of Financial and Quantitative Analysis, forthcoming.

Shleifer, A., and R. W. Vishny, 1986, "Large shareholders and corporate control," Journal of Political Economy, 94(3, Part 1), 461-488.

Staiger, D., and J. Stock, 1997, "Instrumental variables regression with weak instruments," Econometrica, 65(3), 557-586.

Stuart, E. A., 2010, "Matching methods for causal inference: A review and a look forward," Statistical Science, 25(1), 1-21.

Whited, T. M., and G. Wu, 2006, "Financial constraints risk," Review of Financial Studies, 19(2), 531-559. 


\section{Table 1: Sample distribution by bidder type}

The table presents sample distribution by year and bidder type. The sample includes 8,803 completed cashonly mergers and acquisitions resulting in 100\% ownership by the bidder announced between 1997 and 2014. Deal value is in CPI-adjusted 2009 millions of dollars. Data source: Capital IQ.

\begin{tabular}{|c|c|c|c|c|c|c|c|c|}
\hline \multirow[b]{2}{*}{ Year } & \multicolumn{2}{|c|}{ All deals } & \multicolumn{2}{|c|}{ Public bidders } & \multicolumn{2}{|c|}{ Private bidders } & \multicolumn{2}{|c|}{ Fraction of deals } \\
\hline & $n$ & $\begin{array}{c}\text { Deal value } \\
(\$ \mathrm{~m})\end{array}$ & $n$ & $\begin{array}{c}\text { Deal value } \\
(\$ \mathrm{~m})\end{array}$ & $n$ & $\begin{array}{c}\text { Deal value } \\
(\$ \mathrm{~m})\end{array}$ & $\begin{array}{l}\text { Private } \\
\text { bidders }\end{array}$ & $\begin{array}{l}\text { Private } \\
\text { targets }\end{array}$ \\
\hline 1997 & 48 & 10,979 & 23 & 5,528 & 25 & 5,451 & 0.52 & 0.73 \\
\hline 1998 & 153 & 53,868 & 110 & 39,244 & 43 & 14,624 & 0.28 & 0.75 \\
\hline 1999 & 202 & 93,173 & 138 & 74,019 & 64 & 19,154 & 0.32 & 0.70 \\
\hline 2000 & 304 & 140,923 & 239 & 107,839 & 65 & 33,084 & 0.21 & 0.85 \\
\hline 2001 & 351 & 121,313 & 278 & 103,947 & 73 & 17,366 & 0.21 & 0.86 \\
\hline 2002 & 345 & 52,141 & 284 & 49,334 & 61 & 2,807 & 0.18 & 0.91 \\
\hline 2003 & 427 & 62,918 & 344 & 51,056 & 83 & 11,862 & 0.19 & 0.91 \\
\hline 2004 & 520 & 136,207 & 443 & 68,687 & 77 & 67,520 & 0.15 & 0.93 \\
\hline 2005 & 642 & 137,150 & 522 & 115,597 & 120 & 21,553 & 0.19 & 0.92 \\
\hline 2006 & 701 & 187,830 & 587 & 166,579 & 114 & 21,251 & 0.16 & 0.92 \\
\hline 2007 & 773 & 194,880 & 650 & 186,446 & 123 & 8,434 & 0.16 & 0.90 \\
\hline 2008 & 711 & 127,481 & 636 & 113,017 & 75 & 14,464 & 0.11 & 0.92 \\
\hline 2009 & 461 & 100,834 & 404 & 69,581 & 57 & 31,253 & 0.12 & 0.95 \\
\hline 2010 & 748 & 124,948 & 663 & 119,439 & 85 & 5,509 & 0.11 & 0.92 \\
\hline 2011 & 636 & 153,935 & 544 & 143,129 & 92 & 10,806 & 0.14 & 0.93 \\
\hline 2012 & 622 & 129,409 & 554 & 117,654 & 68 & 11,755 & 0.11 & 0.93 \\
\hline 2013 & 578 & 113,396 & 508 & 107,548 & 70 & 5,848 & 0.12 & 0.93 \\
\hline 2014 & 581 & 137,591 & 531 & 132,173 & 50 & 5,418 & 0.09 & 0.95 \\
\hline Total & 8,803 & $2,078,976$ & 7,458 & $1,770,817$ & 1,345 & 308,159 & 0.15 & 0.91 \\
\hline
\end{tabular}




\section{Table 2: Summary statistics on bidder and deal characteristics}

The table presents descriptive statistics for bidder and deal characteristics for a sample of 1,345 deals undertaken by private bidders and 7,458 deals undertaken by public bidders. Panel A reports private bidder characteristics and Panel B public bidder characteristics. Symbols ***,**, and * next to the means and medians indicate statistically significant differences between private and public bidders at the $1 \%, 5 \%$ and $10 \%$ levels, respectively. All variables are defined in the Appendix.

\begin{tabular}{|c|c|c|c|c|c|c|c|}
\hline & Mean & Median & Std & p5 & $\mathrm{p} 25$ & p75 & p95 \\
\hline \multicolumn{8}{|c|}{ Panel A: Private bidders } \\
\hline Total assets $(\$ \mathrm{~m})$ & $4,306.490 * * *$ & $661.632 * * *$ & $12,394.703$ & 14.826 & 211.290 & $1,879.355$ & $22,912.148$ \\
\hline Operating income & $431.900 * * *$ & $70.189 * * *$ & $1,278.120$ & -2.130 & 24.656 & 177.849 & $2,122.430$ \\
\hline Return on assets & $0.204 * * *$ & $0.106 * * *$ & 0.396 & -0.050 & 0.065 & 0.170 & 1.114 \\
\hline$\Delta \mathrm{ROA}\left(\Omega_{2}, 1\right)$ & $0.138 *$ & 0.027 & 0.726 & -0.721 & -0.214 & 0.252 & 1.623 \\
\hline Asset turnover & $0.948 * * *$ & $0.751 * * *$ & 0.823 & 0.107 & 0.369 & 1.193 & 2.639 \\
\hline$\Delta$ ATO $\left(\_2,1\right)$ & 0.026 & $0.013 * * *$ & 0.341 & -0.491 & -0.131 & 0.115 & 0.671 \\
\hline Return on sales (ROS) & $0.222 * * *$ & 0.166 & 0.314 & -0.131 & 0.078 & 0.336 & 1.000 \\
\hline Leverage & $0.425 * * *$ & $0.444 * * *$ & 0.331 & 0.000 & 0.141 & 0.610 & 1.046 \\
\hline Cash & $0.097 * * *$ & $0.04 * * *$ & 0.148 & 0.000 & 0.012 & 0.104 & 0.461 \\
\hline Age & $33.69 * * *$ & $20.000 * * *$ & 35.776 & 2.000 & 8.000 & 45.000 & 119.000 \\
\hline Segment & $1.635 * * *$ & $1.000 * * *$ & 1.355 & 1.000 & 1.000 & 1.000 & 5.000 \\
\hline Tangibility & $0.266^{* * * *}$ & $0.189 * * *$ & 0.243 & 0.011 & 0.070 & 0.401 & 0.805 \\
\hline Capital expenditure & $0.052 *$ & $0.026 * * *$ & 0.076 & 0.000 & 0.007 & 0.061 & 0.207 \\
\hline$R \& D$ & $0.014 * * *$ & $0.000 * * *$ & 0.040 & 0.000 & 0.000 & 0.002 & 0.106 \\
\hline Sales growth & $0.372 * * *$ & $0.129 * *$ & 0.813 & -0.153 & 0.030 & 0.379 & 1.821 \\
\hline Deal value & 239.249 & $27.380 * * *$ & $1,895.975$ & 0.995 & 7.819 & 103.211 & 760.234 \\
\hline Relative size & $0.264 * * *$ & $0.057 * * *$ & 0.562 & 0.001 & 0.013 & 0.206 & 1.520 \\
\hline Private target & 0.921 & 1.000 & 0.270 & 0.000 & 1.000 & 1.000 & 1.000 \\
\hline Non-US target & $0.103 * * *$ & $0.000 * * *$ & 0.305 & 0.000 & 0.000 & 0.000 & 1.000 \\
\hline Hostile & 0.001 & 0.000 & 0.027 & 0.000 & 0.0000 & 0.000 & 0.000 \\
\hline Solicited & $0.097 * * *$ & $0.000 * * *$ & 0.297 & 0.000 & 0.000 & 0.000 & 1.000 \\
\hline Diversifying & $0.303^{* *}$ & $0.000 * *$ & 0.460 & 0.000 & 0.000 & 1.000 & 1.000 \\
\hline Deal order & $2.700 * * *$ & $1.000 * * *$ & 3.763 & 1.000 & 1.000 & 3.000 & 9.000 \\
\hline \multicolumn{8}{|c|}{ Panel B: Public bidders } \\
\hline Total assets $(\$ \mathrm{~m})$ & $7,209.538$ & $1,383.207$ & $16,147.945$ & 70.245 & 457.076 & $4,943.567$ & $39,885.849$ \\
\hline Operating income & $1,241.960$ & 177.179 & $3,234.455$ & 3.697 & 50.923 & 649.235 & $7,674.837$ \\
\hline Return on assets & 0.150 & 0.136 & 0.089 & 0.027 & 0.090 & 0.196 & 0.324 \\
\hline$\Delta \mathrm{ROA}\left({ }_{2}-1\right)$ & 0.102 & 0.017 & 0.528 & -0.525 & -0.125 & 0.178 & 1.054 \\
\hline Asset turnover & 1.003 & 0.838 & 0.679 & 0.232 & 0.534 & 1.249 & 2.479 \\
\hline$\Delta$ ATO $(22-1)$ & -0.001 & -0.001 & 0.201 & -0.362 & -0.093 & 0.085 & 0.347 \\
\hline Return on sales (ROS) & 0.207 & 0.164 & 0.159 & 0.020 & 0.093 & 0.294 & 0.532 \\
\hline Leverage & 0.214 & 0.190 & 0.184 & 0.000 & 0.047 & 0.325 & 0.574 \\
\hline Cash & 0.163 & 0.097 & 0.171 & 0.005 & 0.031 & 0.240 & 0.553 \\
\hline Age & 47.585 & 32.000 & 39.851 & 6.000 & 17.000 & 73.000 & 130.000 \\
\hline Segment & 3.318 & 3.000 & 1.701 & 1.000 & 3.000 & 4.000 & 6.000 \\
\hline Tangibility & 0.224 & 0.145 & 0.216 & 0.022 & 0.069 & 0.302 & 0.746 \\
\hline Capital expenditure & 0.045 & 0.030 & 0.047 & 0.005 & 0.016 & 0.055 & 0.146 \\
\hline$R \& D$ & 0.031 & 0.003 & 0.046 & 0.000 & 0.000 & 0.049 & 0.135 \\
\hline Sales growth & 0.164 & 0.114 & 0.272 & -0.201 & 0.025 & 0.247 & 0.712 \\
\hline Deal value & 237.426 & 36.255 & 916.374 & 1.636 & 10.634 & 137.346 & 911.990 \\
\hline Relative size & 0.092 & 0.029 & 0.164 & 0.001 & 0.009 & 0.091 & 0.456 \\
\hline Private target & 0.908 & 1.000 & 0.289 & 0.000 & 1.000 & 1.000 & 1.000 \\
\hline Non-US target & 0.181 & 0.000 & 0.385 & 0.000 & 0.000 & 0.000 & 1.000 \\
\hline Hostile & 0.001 & 0.000 & 0.031 & 0.000 & 0.000 & 0.000 & 0.000 \\
\hline Solicited & 0.071 & 0.000 & 0.256 & 0.000 & 0.000 & 0.000 & 1.000 \\
\hline Diversifying & 0.272 & 0.000 & 0.445 & 0.000 & 0.000 & 1.000 & 1.000 \\
\hline Deal order & 5.360 & 3.000 & 5.485 & 1.000 & 2.000 & 7.000 & 17.000 \\
\hline
\end{tabular}




\section{Table 3: Operating performance changes around takeovers: full sample}

This table reports full sample comparisons of mean operating performance changes, $\Delta \operatorname{ROA}(1,+j)$ and $\Delta$ $\operatorname{ATO}(1,+j)(j=1,2,3)$, around acquisition deals undertaken by public and private bidders. Year_1 is the last fiscal year prior to deal completion. Year $+i$ is the $i$ th fiscal year after deal completion. Industry-adjusted performance changes are net of the contemporaneous median performance change of all firms in the bidder's 2-digit SIC industry. Bidders are purged from the computation of industry medians. Control-firm-adjusted performance changes are net of the contemporaneous performance change of a control firm. Control firms with the level of pre-deal ROA closest to that of the bidder are selected from the same 2-digit SIC industry, year, and private/public type. Symbols $* * *, * *$, and * denote statistics that are significantly different from zero at the $1 \%, 5 \%$ and $10 \%$ levels, respectively. All variables are defined in the Appendix.

\begin{tabular}{|c|c|c|c|}
\hline & \multicolumn{3}{|c|}{ From year $i$ to year $j$} \\
\hline & -1 to +1 & -1 to +2 & -1 to +3 \\
\hline & \multicolumn{3}{|c|}{ Private bidders } \\
\hline$\Delta$ Return on assets (ROA) & $0.0796^{* * *}$ & $0.0744 * * *$ & $0.0692 * * *$ \\
\hline$\Delta$ Asset turnover (ATO) & $0.0348 * * *$ & $0.0439 * * *$ & $0.0514 * * *$ \\
\hline Industry-adjusted $\Delta \mathrm{ROA}$ & $0.0489 * * *$ & $0.0611 * * *$ & $0.0317 * * *$ \\
\hline Industry-adjusted $\Delta$ ATO & $0.0231 * * *$ & $0.0298 * * *$ & $0.0407 * * *$ \\
\hline Control-firm-adjusted $\Delta$ ROA & $0.0605^{* * *}$ & $0.0326 * * *$ & $0.0301 * * *$ \\
\hline \multirow[t]{2}{*}{ Control-firm-adjusted $\Delta$ ATO } & $0.0343^{* * *}$ & $0.0529 * * *$ & $0.0767 * * *$ \\
\hline & \multicolumn{3}{|c|}{ Public bidders } \\
\hline $\begin{array}{l}\Delta \text { Return on assets (ROA) } \\
\Delta \text { Return on assets (ATO) }\end{array}$ & $-0.0077 * * * *$ & $\begin{array}{l}-0.0131 * * * \\
-0.0231 * * *\end{array}$ & $=0.8207 * * * * 10$ \\
\hline Industry-adjusted $\Delta \mathrm{ROA}$ & $-0.0138 * * *$ & -0.0011 & $-0.0175^{* * *}$ \\
\hline Industry-adjusted $\Delta$ ATO & $-0.0265 * * *$ & $-0.0242 * * *$ & $-0.0149^{* * *}$ \\
\hline Control-firm-adjusted $\Delta \mathrm{ROA}$ & $-0.0075 * * *$ & $-0.0101 * * *$ & $-0.0123^{* * *}$ \\
\hline \multirow[t]{2}{*}{ Control-firm-adjusted $\Delta$ ATO } & $-0.0046^{*}$ & $0.0075 * *$ & $0.0133 * * *$ \\
\hline & \multicolumn{3}{|c|}{ Private bidders - Public bidders } \\
\hline$\Delta$ Return on assets (ROA) & $0.0873 * * *$ & $0.0875 * * *$ & $0.0899 * * *$ \\
\hline$\Delta$ Asset turnover (ATO) & $0.0509 * * *$ & $0.067 * * *$ & $0.0743 * * *$ \\
\hline Industry-adjusted $\Delta \mathrm{ROA}$ & $0.0627 * * *$ & $0.0622 * * *$ & $0.0492 * * *$ \\
\hline Industry-adjusted $\Delta \mathrm{ATO}$ & $0.0496 * * *$ & $0.0540 * * *$ & $0.0556 * * *$ \\
\hline Control-firm-adjusted $\Delta$ ROA & $0.0680 * * *$ & $0.0427 * * *$ & $0.0424 * * *$ \\
\hline Control-firm-adjusted $\Delta$ ATO & $0.0389 * * *$ & $0.0454 * * *$ & $0.0634 * * *$ \\
\hline
\end{tabular}




\section{Table 4: Matching private bidders to public bidders}

The table reports the details of propensity score matching private bidders to public bidders. The type of matching performed is variable ratio $(k: 1)$ nearest neighbor matching with replacement $(k=1, \ldots, 5)$. Panel A reports the estimation results of the propensity score probit model. Industry (2-digit SIC) and year fixed effects are included. Panel A also reports post-matching covariate balance (mean differences and the associated $t$-statistics) for private bidders and their matched public bidders. Panel B reports the number of successfully matched private bidders and the distribution of the number of matches. Symbols *, **, *** denote statistical significance at the $10 \%, 5 \%$, and $1 \%$ levels, respectively. All variables are defined in the Appendix.

\begin{tabular}{|c|c|c|c|}
\hline \multicolumn{4}{|c|}{ Panel A: Propensity score estimation and diagnostics } \\
\hline \multicolumn{2}{|c|}{ Dependent variable: PrivateBidder (probit) } & \multirow{2}{*}{$\begin{array}{c}\text { Differences after PSM } \\
-0.0335\end{array}$} & \multirow{2}{*}{$\begin{array}{l}\text { t-stat } \\
-1.61\end{array}$} \\
\hline Log(revenue) & $\begin{array}{c}-0.031^{* *} \\
(0.016)\end{array}$ & & \\
\hline $\operatorname{ROA}(-1)$ & $\begin{array}{c}0.571 * * * \\
(0.103)\end{array}$ & $0.0303 * * *$ & 2.57 \\
\hline$\Delta \mathrm{ROA}(-2,-1)$ & $\begin{array}{r}0.010 \\
(0.029)\end{array}$ & -0.0282 & 0.87 \\
\hline Log(age) & $\begin{array}{c}-0.081 * * * \\
(0.025)\end{array}$ & -0.0588 & -1.48 \\
\hline Cash & $\begin{array}{c}-1.212 * * * \\
(0.212)\end{array}$ & -0.0049 & -1.19 \\
\hline Leverage & $\begin{array}{c}1.855^{* * *} * \\
(0.110)\end{array}$ & 0.0088 & 0.36 \\
\hline Capital expenditure & $\begin{array}{c}0.390 \\
(0.422)\end{array}$ & -0.0023 & -0.60 \\
\hline Tangibility & $\begin{array}{c}-0.560 * * * \\
(0.167)\end{array}$ & -0.0182 & -1.19 \\
\hline Sales growth & $\begin{array}{c}0.010 \\
(0.010)\end{array}$ & -0.0738 & -0.59 \\
\hline Segment & $\begin{array}{c}-0.388 * * * \\
(0.025)\end{array}$ & -0.0927 & -1.31 \\
\hline$R \& D$ & $\begin{array}{c}0.482 \\
(0.399)\end{array}$ & \multirow[t]{5}{*}{-0.0006} & \multirow[t]{5}{*}{-0.21} \\
\hline Industry FEs & Yes & & \\
\hline Year FEs & Yes & & \\
\hline Observations & 8,214 & & \\
\hline Pseudo $R^{2}$ & 0.344 & & \\
\hline \multicolumn{4}{|c|}{ Panel B: Number of matches } \\
\hline Private bidder with & \multicolumn{2}{|r|}{ Number } & Fraction \\
\hline One public bidder match & \multicolumn{2}{|r|}{52} & 5.78 \\
\hline Two public bidder matches & \multicolumn{2}{|r|}{30} & 3.34 \\
\hline Three public bidder matches & \multicolumn{2}{|r|}{36} & 4.00 \\
\hline Four public bidder matches & \multicolumn{2}{|r|}{45} & 5.01 \\
\hline Five public bidder matches & \multicolumn{2}{|r|}{736} & 81.87 \\
\hline Total & \multicolumn{2}{|r|}{899} & 100.00 \\
\hline
\end{tabular}




\section{Table 5: Operating performance changes around takeovers: matching estimator}

The table reports comparisons of operating performance changes, $\Delta \operatorname{ROA}(\underline{1},+j)$ and $\Delta \operatorname{ATO}(\underline{1},+j)$ $(j=1,2,3)$, around acquisition deals between private and public bidders using a matching estimator. Panel A reports univariate differences. Panel B reports the results of further regression adjustment. The matching estimator is implemented by regressing the outcome variable on the private bidder indicator (with or without controls) and a fixed effect that uniquely identifies each private bidder and its matched public bidder(s) (stack fixed effects). Each stack is weighted equally (private bidders receive the weight of 1, public bidders receive the weight of $1 / n$, where $n$ is the number of control public bidders in the stack). Standard errors clustered at the stack level are reported in parentheses. Symbols *, **, or *** denote statistical significance at the $10 \%, 5 \%$, or $1 \%$ level, respectively. All variables are defined in the Appendix.

\begin{tabular}{|c|c|c|c|c|c|c|}
\hline \multirow[b]{4}{*}{ Private-public } & \multicolumn{3}{|c|}{$\Delta \mathrm{ROA}$} & \multicolumn{3}{|c|}{$\Delta \mathrm{ATO}$} \\
\hline & $(-1,+1)$ & $(-1,+2)$ & $(-1,+3)$ & $(-1,+1)$ & $(-1,+2)$ & $(-1,+3)$ \\
\hline & \multicolumn{6}{|c|}{ Panel A: Univariate comparison } \\
\hline & $0.0812 * * *$ & $0.1069 * * *$ & $0.0750 * * *$ & $0.0539 * * *$ & $0.0643 * * *$ & $0.0569 * * *$ \\
\hline & \multicolumn{6}{|c|}{ Panel B: Regression adjustment } \\
\hline Private bidder & $\begin{array}{c}0.073 * * * \\
(0.017)\end{array}$ & $\begin{array}{c}0.095 * * * \\
(0.022)\end{array}$ & $\begin{array}{c}0.067 * * * \\
(0.025)\end{array}$ & $\begin{array}{c}0.053 * * * \\
(0.011)\end{array}$ & $\begin{array}{c}0.063 * * * \\
(0.014)\end{array}$ & $\begin{array}{c}0.052 * * * \\
(0.016)\end{array}$ \\
\hline ROA/ATO( _ 1) & $\begin{array}{l}0.598 * * * \\
(0.109)\end{array}$ & $\begin{array}{c}-0.485^{* * * *} \\
(0.181)\end{array}$ & $\begin{array}{l}-0.733^{* * * *} \\
(0.247)\end{array}$ & $-\begin{array}{l}0.074 * * * \\
(0.007)\end{array}$ & $-\begin{array}{c}0.096 * * * \\
(0.012)\end{array}$ & $-\begin{array}{l}0.111 * * * \\
(0.011)\end{array}$ \\
\hline$\Delta$ ROA/ATO $(2,-1)$ & $\begin{array}{l}2.090 * * * \\
(0.302)\end{array}$ & $-\begin{array}{l}1.624 * * * \\
(0.286)\end{array}$ & $-\begin{array}{l}1.516^{* * * *} \\
(0.245)\end{array}$ & $\begin{array}{r}0.023 \\
(0.019)\end{array}$ & $\begin{array}{r}0.022 \\
(0.022)\end{array}$ & $\begin{array}{c}0.038 * * \\
(0.018)\end{array}$ \\
\hline $\log ($ revenue $)$ & $\begin{array}{c}0.000 \\
(0.006)\end{array}$ & $\begin{array}{l}0.002 \\
(0.007)\end{array}$ & $\begin{array}{c}0.012 \\
(0.007)\end{array}$ & $-\begin{array}{l}0.010 * * * \\
(0.004)\end{array}$ & $\begin{array}{l}0.000 \\
(0.004)\end{array}$ & $\begin{array}{l}-0.008 \\
(0.005)\end{array}$ \\
\hline Private target & $\frac{0.046^{*}}{(0.024)}$ & $\begin{array}{l}-0.006 \\
(0.036)\end{array}$ & $\begin{array}{l}-0.013 \\
(0.032)\end{array}$ & $\begin{array}{r}0.016 \\
(0.017)\end{array}$ & $\begin{array}{c}0.040 * * \\
(0.017)\end{array}$ & $\frac{0.039 *}{(0.020)}$ \\
\hline Non-US target & $\begin{array}{c}0.004 \\
(0.021)\end{array}$ & $\begin{array}{l}0.042 * \\
(0.024)\end{array}$ & $\begin{array}{c}0.016 \\
(0.024)\end{array}$ & $\begin{array}{c}0.014 \\
(0.014)\end{array}$ & $\begin{array}{c}0.002 \\
(0.018)\end{array}$ & $\begin{array}{c}0.005 \\
(0.017)\end{array}$ \\
\hline Relative size & $-\frac{0.133 * *}{(0.058)}$ & $\begin{array}{c}0.188^{* *} \\
(0.073)\end{array}$ & $\begin{array}{l}-0.249 * * * \\
(0.074)\end{array}$ & $-\begin{array}{l}0.245^{* * *} \\
(0.045)\end{array}$ & $\begin{array}{l}-0.223 * * * \\
(0.046)\end{array}$ & $-\begin{array}{l}0.281 * * * \\
(0.050)\end{array}$ \\
\hline Squared relative size & $\begin{array}{l}-0.002 * * * \\
(0.000)\end{array}$ & $\begin{array}{l}-0.002 * * * \\
(0.000)\end{array}$ & $\begin{array}{c}-0.002 * * * \\
(0.000)\end{array}$ & $\begin{array}{c}0.000 * * * \\
(0.000)\end{array}$ & $\begin{array}{l}-0.000 \\
(0.000)\end{array}$ & $\begin{array}{c}0.002 * * * \\
(0.000)\end{array}$ \\
\hline $\log ($ age $)$ & $\begin{array}{l}-0.004 \\
(0.009)\end{array}$ & $\overline{-}_{(0.011)}^{0.013}$ & $\frac{-0.025^{* *}}{(0.011)}$ & $\begin{array}{c}0.001 \\
(0.006)\end{array}$ & $\begin{array}{l}-0.003 \\
(0.007)\end{array}$ & $\begin{array}{l}0.001 \\
(0.008)\end{array}$ \\
\hline Hostile & $\begin{array}{c}0.287 * * * \\
(0.033)\end{array}$ & $\begin{array}{c}0.159 * * \\
(0.078)\end{array}$ & $\begin{array}{c}0.076 \\
(0.114)\end{array}$ & $\begin{array}{c}0.123 * * * \\
(0.028)\end{array}$ & $\begin{array}{c}0.048 \\
(0.044)\end{array}$ & $\begin{array}{c}0.100 \\
(0.083)\end{array}$ \\
\hline Solicited & $\begin{array}{c}0.004 \\
(0.032)\end{array}$ & $\begin{array}{c}0.003 \\
(0.033)\end{array}$ & $\begin{array}{c}0.004 \\
(0.031)\end{array}$ & $-_{(0.020)}^{0.018}$ & $\begin{array}{c}0.026 \\
(0.024)\end{array}$ & $\begin{array}{c}0.027 \\
(0.020)\end{array}$ \\
\hline Diversifying & $\begin{array}{c}0.023 \\
(0.016)\end{array}$ & $\begin{array}{l}0.011 \\
(0.021)\end{array}$ & $\begin{array}{l}0.001 \\
(0.022)\end{array}$ & $\begin{array}{c}0.008 \\
(0.011)\end{array}$ & $\begin{array}{l}-0.004 \\
(0.014)\end{array}$ & $\begin{array}{l}-0.001 \\
(0.015)\end{array}$ \\
\hline Deal order & $\begin{array}{l}0.002 * * \\
(0.001)\end{array}$ & $\begin{array}{c}0.001 \\
(0.001)\end{array}$ & $\begin{array}{l}0.003 * * \\
(0.002)\end{array}$ & $\begin{array}{l}0.002 * * \\
(0.001)\end{array}$ & $\begin{array}{c}0.004 * * * \\
(0.001)\end{array}$ & $\begin{array}{l}0.003^{*} \\
(0.001)\end{array}$ \\
\hline Stack FEs & Yes & Yes & Yes & Yes & Yes & Yes \\
\hline Observations & 4,276 & 4,226 & 4,165 & 4,336 & 4,252 & 4,230 \\
\hline Adj. R-squared & 0.474 & 0.403 & 0.425 & 0.337 & 0.338 & 0.386 \\
\hline
\end{tabular}




\section{Table 6: Instrumenting listing status with VC availability at founding}

The table reports the results of instrumental variable (IV) analysis of operating performance changes, $\Delta$ $\operatorname{ROA}(1,+j)$ or $\Delta \operatorname{ATO}(1,+j)(j=1,2,3)$, around acquisitions deals for public and private bidders. Panel A reports estimation results of the first step probit regression of the PrivateBidder indicator on the instrument (VCsupply at founding) and all other covariates. Panel B reports estimation results of the first-stage regression of the 2SLS model, where the PrivateBidderindicator is regressed on the predicted probability from the probit model reported in Panel A and all other covariates. The $F$-test for the significance of the excluded instrument is also reported. Panel $\mathrm{C}$ reports estimation results of the second-stage regression of the main outcome variables on the instrumented private bidder indicator. Only the coefficients of interests are shown; other covariates in all three models are the same as those in Panel B of Table 5. Industry (2-digit SIC) and year fixed effects are included in all models. Standard errors clustered at the firm level are reported in parentheses. Symbols *, **, or *** denote statistical significance at the $10 \%, 5 \%$, or $1 \%$ level, respectively. All variables are defined in the Appendix.

\begin{tabular}{|c|c|c|c|c|c|c|}
\hline \multicolumn{7}{|c|}{ Panel A: First step probit regression } \\
\hline VCsupply at founding & $\begin{array}{c}0.820 * * * \\
(0.249)\end{array}$ & $\begin{array}{l}-0.754 * * * \\
(0.251)\end{array}$ & $-\begin{array}{l}0.819 * * * \\
(0.263)\end{array}$ & $-\begin{array}{l}0.658 * * * \\
(0.238)\end{array}$ & $\begin{array}{c}0.646 * * * \\
(0.240)\end{array}$ & $\begin{array}{c}0.545^{* *} \\
(0.232)\end{array}$ \\
\hline Pseudo $R^{2}$ & 0.219 & 0.217 & 0.215 & 0.211 & 0.209 & 0.212 \\
\hline Observations & 4,357 & 4,333 & 4,247 & 4,221 & 4,120 & 4,076 \\
\hline \multicolumn{7}{|c|}{ Panel B: 2SLS first-stage regression } \\
\hline Prob(Private bidder) & $\begin{array}{c}0.744 * * * \\
(0.110)\end{array}$ & $\begin{array}{c}0.788 * * * \\
(0.111)\end{array}$ & $\begin{array}{c}0.833 * * * \\
(0.114)\end{array}$ & $\begin{array}{c}0.804 * * * \\
(0.117)\end{array}$ & $\begin{array}{c}0.834 * * * \\
(0.119)\end{array}$ & $\begin{array}{c}0.996 * * * \\
(0.125)\end{array}$ \\
\hline$F_{-}$stat & 45.14 & 49.74 & 53.22 & 46.79 & 48.45 & 63.08 \\
\hline Observations & 4,357 & 4,333 & 4,247 & 4,221 & 4,120 & 4,076 \\
\hline \multicolumn{7}{|c|}{ Panel C: 2SLS second-stage regression } \\
\hline & \multicolumn{3}{|c|}{$\Delta \mathrm{ROA}$} & \multicolumn{3}{|c|}{$\Delta$ ATO } \\
\hline & $(-1,+1)$ & $(-1,+2)$ & $(-1,+3)$ & $(-1,+1)$ & $(-1,+2)$ & $(-1,+3)$ \\
\hline Private bidder & $\begin{array}{c}0.537 * * * \\
(0.185)\end{array}$ & $\begin{array}{c}0.676 * * * \\
(0.222)\end{array}$ & $\begin{array}{c}0.418 * * \\
(0.191)\end{array}$ & $\begin{array}{c}0.281 * * * \\
(0.099)\end{array}$ & $\begin{array}{c}0.257 * * \\
(0.117)\end{array}$ & $\begin{array}{c}0.330 * * \\
(0.135)\end{array}$ \\
\hline Observations & 4,357 & 4,333 & 4,247 & 4,221 & 4,120 & 4,076 \\
\hline R-squared & 0.143 & 0.064 & 0.172 & 0.082 & 0.136 & 0.116 \\
\hline
\end{tabular}




\section{Table 7: The Agency cost channel}

The table reports comparisons of operating performance changes, $\Delta \operatorname{RO} \underline{A}(1,+j)$ and $\Delta \operatorname{ATO}(1,+j)$ $(j=1,2,3)$, around acquisition deals between private and public bidders using a matching estimator with further regression adjustment, conditional on the type of private bidder. The sample is subset into low, medium, and high according the value of the governance characteristic of the private bidder using terciles of the distribution. In Panel A the sub-setting variable is CEO ownership. In Panel B the sub-setting variable is ownership by top 1 outside shareholder. In Panel $C$ the sub-setting variable is the takeover defence score. The matching estimator is implemented by regressing the outcome variable on the private bidder indicator, control variables, and a fixed effect that uniquely identifies each private bidder and its matched public bidder(s) (stack fixed effects). Each stack is weighted equally (private bidders receive the weight of 1 , public bidders receive the weight of $1 / n$, where $n$ is the number of control public bidders in the stack). Standard errors clustered at the stack level are reported in parentheses. Symbols *,**, or *** denote statistical significance at the $10 \%, 5 \%$, or $1 \%$ level, respectively. Only the coefficients of interests are shown. The specifications are otherwise identical to those in Table 5. All variables are defined in the Appendix.

\begin{tabular}{|c|c|c|c|c|c|c|}
\hline & \multicolumn{3}{|c|}{$\Delta \mathrm{ROA}$} & \multicolumn{3}{|c|}{$\Delta \mathrm{ATO}$} \\
\hline & $(-1,+1)$ & $(-1,+2)$ & $(-1,+3)$ & $(-1,+1)$ & $(-1,+2)$ & $(-1,+3)$ \\
\hline \multicolumn{7}{|c|}{ Panel A: CEO ownership } \\
\hline Low: Private bidder & $\begin{array}{c}-0.048 \\
(0.035)\end{array}$ & $\begin{array}{l}-0.057 \\
(0.042)\end{array}$ & $\begin{array}{l}-0.052 \\
(0.046)\end{array}$ & $\begin{array}{c}-0.053 * * \\
(0.023)\end{array}$ & $\begin{array}{c}-0.059 * * \\
(0.024)\end{array}$ & $\begin{array}{c}-0.076 * * * * \\
(0.029)\end{array}$ \\
\hline Observations & 1,125 & 1,122 & 1,109 & 1,106 & 1,103 & 1,084 \\
\hline Medium: Private bidder & $\begin{array}{c}0.100 * * * \\
(0.031)\end{array}$ & $\begin{array}{c}0.083 * * \\
(0.035)\end{array}$ & $\begin{array}{l}0.064 * \\
(0.033)\end{array}$ & $\begin{array}{c}0.092 * * * \\
(0.021)\end{array}$ & $\begin{array}{c}0.101 * * * \\
(0.024)\end{array}$ & $\begin{array}{c}0.077 * * \\
(0.031)\end{array}$ \\
\hline Observations & 1,103 & 1,093 & 1,058 & 1,084 & 1,083 & 1,067 \\
\hline High: Private bidder & $\begin{array}{c}0.169 * * * \\
(0.044)\end{array}$ & $\begin{array}{c}0.136 * * \\
(0.059)\end{array}$ & $\begin{array}{c}0.039 \\
(0.064)\end{array}$ & $\begin{array}{c}0.211 * * * \\
(0.029)\end{array}$ & $\begin{array}{c}0.339 * * * \\
(0.040)\end{array}$ & $\begin{array}{c}0.365 * * * \\
(0.047)\end{array}$ \\
\hline Observations & 1,027 & 1,002 & 983 & 1,019 & 987 & 978 \\
\hline \multicolumn{7}{|c|}{ Panel B: Outside top1 ownership } \\
\hline Low: Private bidder & $\begin{array}{c}0.063 \\
(0.047)\end{array}$ & $\begin{array}{c}0.031 \\
(0.071)\end{array}$ & $\begin{array}{c}0.004 \\
(0.069)\end{array}$ & $\begin{array}{c}0.033 \\
(0.037)\end{array}$ & $\begin{array}{c}0.016 \\
(0.035)\end{array}$ & $\begin{array}{c}0.025 \\
(0.044)\end{array}$ \\
\hline Observations & 658 & 651 & 637 & 601 & 581 & 583 \\
\hline Medium: Private bidder & $\begin{array}{c}0.011 \\
(0.037)\end{array}$ & $\begin{array}{c}0.035 \\
(0.051)\end{array}$ & $\begin{array}{c}0.030 \\
(0.051)\end{array}$ & $\begin{array}{c}0.056 * * \\
(0.025)\end{array}$ & $\begin{array}{c}0.049 \\
(0.037)\end{array}$ & $\begin{array}{c}0.093 * * * \\
(0.035)\end{array}$ \\
\hline Observations & 617 & 609 & 616 & 582 & 586 & 595 \\
\hline High: Private bidder & $\begin{array}{c}0.107 * * * \\
(0.038)\end{array}$ & $\begin{array}{c}0.157 * * * \\
(0.040)\end{array}$ & $\begin{array}{c}0.208 * * * \\
(0.068)\end{array}$ & $\begin{array}{c}0.073 * * * \\
(0.028)\end{array}$ & $\begin{array}{c}0.132 * * * \\
(0.033)\end{array}$ & $\begin{array}{c}0.149 * * * \\
(0.047)\end{array}$ \\
\hline Observations & 551 & 533 & 520 & 599 & 600 & 570 \\
\hline \multicolumn{7}{|c|}{ Panel C: Takeover defence score } \\
\hline Low: Private bidder & $\begin{array}{c}0.055 * * \\
(0.025)\end{array}$ & $\begin{array}{l}0.056^{*} \\
(0.031)\end{array}$ & $\begin{array}{c}0.054 \\
(0.039)\end{array}$ & $\begin{array}{c}0.056 * * * \\
(0.020)\end{array}$ & $\begin{array}{c}0.101 * * * \\
(0.025)\end{array}$ & $\begin{array}{c}0.030 \\
(0.027)\end{array}$ \\
\hline Observations & 1,429 & 1,408 & 1,368 & 1,431 & 1,427 & 1,386 \\
\hline Medium: Private bidder & $\begin{array}{c}0.073 * * \\
(0.033)\end{array}$ & $\begin{array}{c}0.129 * * * \\
(0.042)\end{array}$ & $\begin{array}{c}0.030 \\
(0.037)\end{array}$ & $\begin{array}{c}0.046 * * \\
(0.021)\end{array}$ & $\begin{array}{c}0.041 \\
(0.026)\end{array}$ & $\begin{array}{c}0.069 * * \\
(0.031)\end{array}$ \\
\hline Observations & 1,325 & 1,294 & 1,293 & 1,304 & 1,275 & 1,262 \\
\hline High: Private bidder & $\begin{array}{c}0.023 \\
(0.032)\end{array}$ & $\begin{array}{c}-0.081 * * \\
(0.037)\end{array}$ & $\begin{array}{l}-0.049 \\
(0.043)\end{array}$ & $\begin{array}{c}0.022 \\
(0.020)\end{array}$ & $\begin{array}{c}0.013 \\
(0.020)\end{array}$ & $\begin{array}{c}0.007 \\
(0.023)\end{array}$ \\
\hline Observations & 1,211 & 1,205 & 1,193 & 1,178 & 1,181 & 1,181 \\
\hline
\end{tabular}




\section{Table 8: Sources of private bidder advantage}

The table reports full sample comparisons of, as well as the matching estimator of the difference in, percentage changes in SG\&A, COGS, CAPEX (as a ratio of total assets) between public and private bidders. Year 1 is the last fiscal year prior to deal completion. Year $+i$ is the $i$ th fiscal year after deal completion. The matching estimator is implemented by regressing the variable of interest on the private bidder indicator and a fixed effect that uniquely identifies each private bidder and its matched public bidder(s) (stack fixed effects). Each stack is weighted equally (private bidders receive the weight of 1, public bidders receive the weight of $1 / n$, where $n$ is the number of control public bidders in the stack). Standard errors clustered at the stack level are reported in parentheses. Symbols *,**, or *** denote statistical significance at the $10 \%$, $5 \%$, or $1 \%$ level, respectively. All variables are defined in the Appendix.

\begin{tabular}{|c|c|c|c|}
\hline & \multicolumn{3}{|c|}{ From year $i$ to year $j$} \\
\hline & -1 to +1 & -1 to +2 & -1 to +3 \\
\hline & \multicolumn{3}{|c|}{ Private bidder } \\
\hline SG\&A & $-0.0105 * * *$ & $-0.0118 * * *$ & $-0.0142 * * *$ \\
\hline COGS & $-0.0153 * * *$ & $-0.0189 * * *$ & $-0.0129 * * *$ \\
\hline \multirow[t]{2}{*}{ CAPEX } & $-0.0035^{* * *} *$ & $-0.0071 * * *$ & $-0.0110 * * *$ \\
\hline & \multicolumn{3}{|c|}{ Public bidder } \\
\hline SG\&A & $-0.0058 * * *$ & $-0.0069 * * *$ & $-0.0068 * * *$ \\
\hline COGS & $-0.0137 * * *$ & $-0.0213 * * *$ & $-0.0256^{* * *}$ \\
\hline \multirow[t]{2}{*}{ CAPEX } & $-0.0011 * * *$ & $-0.0023 * * *$ & $-0.0032 * * *$ \\
\hline & \multicolumn{3}{|c|}{ Private bidder - public bidder } \\
\hline SG\&A & $-0.0048 * * *$ & $-0.0050 * *$ & $-0.0073 * * *$ \\
\hline COGS & -0.0016 & 0.0025 & $0.0127 *$ \\
\hline \multirow[t]{2}{*}{ CAPEX } & $-0.0025 * * *$ & $-0.0048 * * *$ & $-0.0078 * * *$ \\
\hline & \multicolumn{3}{|c|}{ Private bidder - matched public bidder } \\
\hline SG\&A & _0.0037*** & {$[0.0037 * * *$} & _0.0059*** \\
\hline COGS & 0.0077 & 0.0101 & 0.0005 \\
\hline CAPEX & $-0.0019 * * *$ & $-0.0029 * * *$ & $-0.0041 * * *$ \\
\hline
\end{tabular}




\section{Table 9: Do private bidders buy more profitable targets?}

The table reports full sample comparisons of target profitability, transaction multiples, and operating performance changes, $\Delta \operatorname{ROA}(1,+j)$ and $\Delta \operatorname{ATO}(1,+j)(j=1,2,3)$, around acquisition deals between public and private bidders. Panel A reports the mean target firm ROA and ATO one year prior to the deal. Panel $\mathrm{B}$ reports the mean percentage change in target firm ROA and ATO one year prior to the deal relative to the year before. Panel C reports mean and median transaction multiples (Deal value/Assets, Deal Value/Sales, and Deal value/Operating Income). Tests for differences are also shown. Panel D reports the coefficient of interest from regressions of transaction multiples on the PrivateBidder indicator and industry (2-digit SIC) and year fixed effects. Panel E reports the coefficient of interest from regressions of $\Delta \operatorname{ROA}(1,+j)$ and $\Delta \operatorname{ATO}(\underline{1},+j)(j=1,2,3)$ on the PrivateBidder indicator, control variables (see Panel B of Table 5), and industry (2-digit SIC) and year fixed effects, except that the dependent variable is computed using the weighted-average performance of the bidder and the target in year $\underline{t} 1$ (with total assets as weights). Standard errors clustered at the firm level are reported in parentheses. Symbols ***, **, and * denote the significant differences at the $1 \%, 5 \%$ and $10 \%$ levels, respectively.

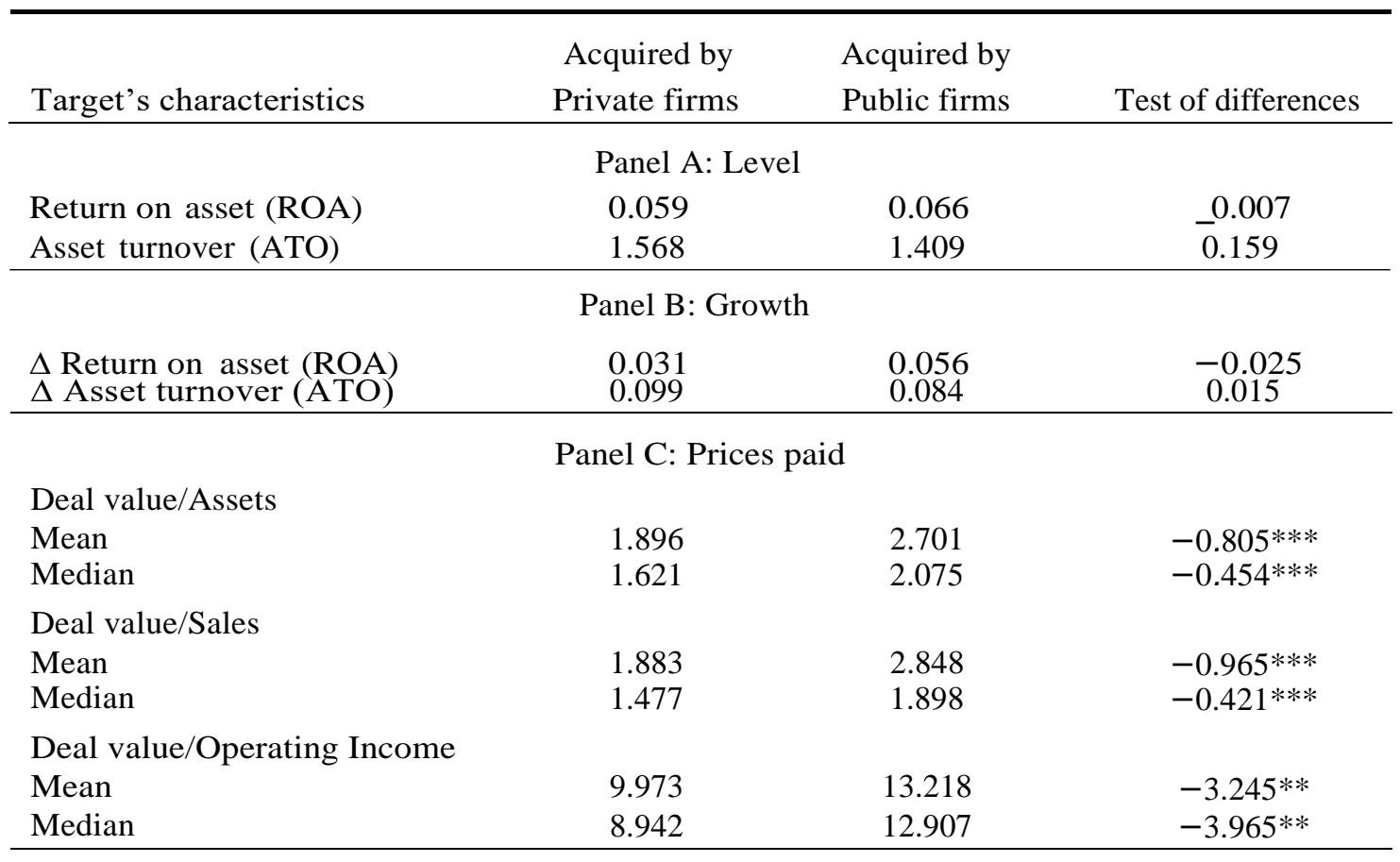

Panel D: Prices paid - regressions

\begin{tabular}{lccc} 
& Deal value/Assets & Deal value/Sales & Deal value/OI \\
Private bidder & $-0.503^{* * *}$ & $-0.759 * * *$ & $-4.408^{* *}$ \\
& $(0.155)$ & $(0.217)$ & $(1.979)$ \\
Observations & 1,212 & 1,214 & 1,216 \\
\hline
\end{tabular}

Panel E: Changes in combined firm performance

\begin{tabular}{cccccccc} 
& \multicolumn{3}{c}{$\Delta$ ROA } & \multicolumn{3}{c}{$\Delta$ ATO } \\
& $(-1,+1)$ & $(-1,+2)$ & $(-1,+3)$ & $(-1,+1)$ & $(-1,+2)$ & $(-1,+3)$ \\
\hline \multirow{2}{*}{ Private bidder } & $0.161^{* *}$ & 0.065 & $0.193^{* *}$ & $0.094^{* * *}$ & $0.106^{* *}$ & $0.166^{* * *}$ \\
& $(0.068)$ & $(0.067)$ & $(0.081)$ & $(0.033)$ & $(0.044)$ & $(0.047)$ \\
Observations & 1,190 & 1,161 & 1,160 & 1,119 & 1,105 & 1,101 \\
\hline
\end{tabular}




\section{Table 10: Merger accounting? Changes in return on sales (ROS)}

The table reports comparisons of changes in return on sales, $\Delta \operatorname{ROS}(1,+j)(j=1,2,3)$, around acquisition deals between private and public bidders in the full sample (Panel A) as well as using a matching estimator with and without further regression adjustment (Panels B and C). Year_1 is the last fiscal year prior to deal completion. Year $+i$ is the $i$ th fiscal year after deal completion. Industry-adjusted performance changes are net of the contemporaneous median performance change of all firms in the bidder's 2-digit SIC industry. Bidders are purged from the computation of industry medians. Control-firm-adjusted performance changes are net of the contemporaneous performance change of a control firm. Control firms with the level of pre-deal ROA closest to that of the bidder are selected from the same 2-digit SIC industry, year, and private/public type. The matching estimator is implemented by regressing the outcome variable on the private bidder indicator (with or without controls) and a fixed effect that uniquely identifies each private bidder and its matched public bidder(s) (stack fixed effects). Each stack is weighted equally (private bidders receive the weight of 1 , public bidders receive the weight of $1 / n$, where $n$ is the number of control public bidders in the stack). Standard errors clustered at the stack level are reported in parentheses. Symbols *,**, or *** denote statistical significance at the $10 \%, 5 \%$, or $1 \%$ level, respectively. Only the coefficients of interests are shown. The specifications are otherwise identical to those in Table 5. All variables are defined in the Appendix.

Panel A: Full sample comparisons

From year $i$ to year $j$

\begin{tabular}{lccc} 
& -1 to +1 & -1 to +2 & -1 to +3 \\
\hline & & Private bidder \\
$\Delta$ Return on sales (ROS) & $0.0789^{* * *}$ & $0.0611^{* * *}$ & $0.0301^{* *}$ \\
Industry-adjusted $\Delta$ ROS & $0.0541^{* * *}$ & $0.0432^{* * *}$ & $0.0191^{* * *}$ \\
Control-firm-adjusted $\Delta$ ROS & $0.0754^{* * *}$ & $0.0686^{* * *}$ & $0.0524^{* * *}$ \\
\hline & & Public bidder \\
$\Delta$ Return on sales (ROS) & $0.0107^{* * *}$ & $-0.0110^{*}$ & -0.0038 \\
Industry-adjusted $\Delta$ ROS & $-0.0141^{* * *}$ & $-0.0183^{* * *}$ & $-0.0293^{* * *}$ \\
Control-firm-adjusted $\Delta$ ROS & $0.0169^{* *}$ & 0.0020 & $-0.0138^{* *}$ \\
\hline & & & \\
& & Private bidder - Public bidder & \\
$\Delta$ Return on sales (ROS) & $0.0682^{* * *}$ & $0.0721^{* * *}$ & $0.0339^{* * *}$ \\
Industry-adjusted $\Delta$ ROS & $0.0682^{* * *}$ & $0.0615^{* * *}$ & $0.0484^{* * *}$ \\
Control-firm-adjusted $\Delta$ ROS & $0.0585^{* * *}$ & $0.0666^{* * *}$ & $0.0662^{* * *}$ \\
\hline
\end{tabular}

Panel B: Matching estimator: univariate

\begin{tabular}{cccc} 
& $\Delta \operatorname{ROS}(-1,+1)$ & $\Delta \operatorname{ROS}(-1,+2)$ & $\Delta \operatorname{ROS}(-1,+3)$ \\
\hline Private-public & $0.0519^{* * *}$ & $0.0576^{* * *}$ & $0.0477^{* * *}$ \\
\hline
\end{tabular}

Panel C: Matching estimator: regression adjustment

$\Delta \operatorname{ROS}(-1,+1) \quad \Delta \operatorname{ROS}(-1,+2) \quad \Delta \operatorname{ROS}(-1,+3)$

\begin{tabular}{lccc} 
Private bidder & $0.034^{* *}$ & $0.036^{* *}$ & $0.035^{* *}$ \\
& $(0.015)$ & $(0.015)$ & $(0.016)$ \\
Observations & 4,356 & 4,252 & 4,249 \\
\hline
\end{tabular}




\section{Table 11: Access to capital}

The table reports comparisons of operating performance changes, $\Delta \operatorname{RO} \underline{A}(1,+j)$ and $\Delta \operatorname{ATO}(1,+j)$ $(j=1,2,3)$, around acquisition deals between private and public bidders using a matching estimator with further regression adjustment, conditional on the type of private bidder. The sample is subset into low, medium, and high according the value of proxies for financing constraints of the private bidder using terciles of the distribution. In Panel A the sub-setting variable is the SA Index of Hadlock and Pierce (2010). In Panel B the sub-setting variable is free cash flow (FCF). In Panel C the sub-setting variable is leverage. The matching estimator is implemented by regressing the outcome variable on the private bidder indicator, control variables, and a fixed effect that uniquely identifies each private bidder and its matched public bidder(s) (stack fixed effects). Each stack is weighted equally (private bidders receive the weight of 1, public bidders receive the weight of $1 / n$, where $n$ is the number of control public bidders in the stack). Standard errors clustered at the stack level are reported in parentheses. Symbols *,**, or *** denote statistical significance at the $10 \%, 5 \%$, or $1 \%$ level, respectively. Only the coefficients of interests are shown. The specifications are otherwise identical to those in Table 5. All variables are defined in the Appendix.

\begin{tabular}{|c|c|c|c|c|c|c|}
\hline & \multicolumn{3}{|c|}{$\triangle \mathrm{ROA}$} & \multicolumn{3}{|c|}{$\triangle \mathrm{ATO}$} \\
\hline & $(-1,+1)$ & $(-1,+2)$ & $(-1,+3)$ & $(-1,+1)$ & $(-1,+2)$ & $(-1,+3)$ \\
\hline \multicolumn{7}{|c|}{ Panel A: SA Index } \\
\hline Low SA index: Private bidder & $\begin{array}{c}0.071 * * \\
(0.029)\end{array}$ & $\begin{array}{c}0.059 \\
(0.038)\end{array}$ & $\begin{array}{l}0.081^{*} \\
(0.044)\end{array}$ & $\begin{array}{c}0.059 * * * \\
(0.018)\end{array}$ & $\begin{array}{c}0.095 * * * \\
(0.024)\end{array}$ & $\begin{array}{c}0.109 * * * \\
(0.024)\end{array}$ \\
\hline Observations & 1,458 & 1,437 & 1,426 & 1,461 & 1,442 & 1,439 \\
\hline Medium SA index: Private bidder & $\begin{array}{c}0.067 * * \\
(0.029)\end{array}$ & $\begin{array}{c}0.127 * * * \\
(0.038)\end{array}$ & $\begin{array}{c}0.018 \\
(0.040)\end{array}$ & $\begin{array}{c}0.063 * * * \\
(0.019)\end{array}$ & $\begin{array}{c}0.078 * * * \\
(0.024)\end{array}$ & $\begin{array}{c}0.086 * * * \\
(0.031)\end{array}$ \\
\hline Observations & 1,404 & 1,399 & 1,358 & 1,425 & 1,400 & 1,392 \\
\hline High SA index: Private bidder & $\begin{array}{c}0.040 \\
(0.038)\end{array}$ & $\begin{array}{c}0.000 \\
(0.043)\end{array}$ & $\begin{array}{c}-0.017 \\
(0.045)\end{array}$ & $\begin{array}{c}0.011 \\
(0.024)\end{array}$ & $\begin{array}{c}-0.005 \\
(0.030)\end{array}$ & $\begin{array}{l}-0.061 * \\
(0.035)\end{array}$ \\
\hline Observations & 1,414 & 1,390 & 1,381 & 1,450 & 1,410 & 1,399 \\
\hline \multicolumn{7}{|c|}{ Panel B: Free Cash Flows (FCF) } \\
\hline Low FCF: Private bidder & $\begin{array}{c}0.071 * * \\
(0.028)\end{array}$ & $\begin{array}{c}0.021 \\
(0.037)\end{array}$ & $\begin{array}{c}0.044 \\
(0.046)\end{array}$ & $\begin{array}{c}0.013 \\
(0.022)\end{array}$ & $\begin{array}{c}-0.024 \\
(0.026)\end{array}$ & $\begin{array}{c}-0.040 \\
(0.032)\end{array}$ \\
\hline Observations & 1,418 & 1,401 & 1,387 & 1,415 & 1,391 & 1,390 \\
\hline Medium FCF: Private bidder & $\begin{array}{c}0.068 * * \\
(0.029)\end{array}$ & $\begin{array}{c}0.067 * \\
(0.035)\end{array}$ & $\begin{array}{c}0.002 \\
(0.033)\end{array}$ & $\begin{array}{c}0.075 * * * \\
(0.019)\end{array}$ & $\begin{array}{c}0.108 * * * \\
(0.024)\end{array}$ & $\begin{array}{c}0.102 * * * \\
(0.030)\end{array}$ \\
\hline Observations & 1,414 & 1,401 & 1,372 & 1,472 & 1,422 & 1,406 \\
\hline High FCF: Private bidder & $\begin{array}{c}0.067^{*} \\
(0.040)\end{array}$ & $\begin{array}{c}0.148 * * * \\
(0.053)\end{array}$ & $\begin{array}{l}0.088 * \\
(0.049)\end{array}$ & $\begin{array}{c}0.067 * * * \\
(0.022)\end{array}$ & $\begin{array}{c}0.077 * * * \\
(0.027)\end{array}$ & $\begin{array}{c}0.077 * * * \\
(0.024)\end{array}$ \\
\hline Observations & 1,444 & 1,424 & 1,406 & 1,449 & 1,439 & 1,434 \\
\hline \multicolumn{7}{|c|}{ Panel C: Leverage } \\
\hline Low leverage: Private bidder & $\begin{array}{c}0.122 * * * \\
(0.035)\end{array}$ & $\begin{array}{c}0.093 * * \\
(0.040)\end{array}$ & $\begin{array}{l}0.085^{*} \\
(0.045)\end{array}$ & $\begin{array}{c}0.095 * * * \\
(0.020)\end{array}$ & $\begin{array}{c}0.105 * * * \\
(0.024)\end{array}$ & $\begin{array}{c}0.126 * * * \\
(0.031)\end{array}$ \\
\hline Observations & 1,435 & 1,439 & 1,408 & 1,418 & 1,415 & 1,390 \\
\hline Medium leverage: Private bidder & $\begin{array}{c}0.073 * * * \\
(0.027)\end{array}$ & $\begin{array}{c}0.135 * * * \\
(0.039)\end{array}$ & $\begin{array}{c}0.056 \\
(0.038)\end{array}$ & $\begin{array}{c}0.063 * * * \\
(0.019)\end{array}$ & $\begin{array}{c}0.079 * * * \\
(0.023)\end{array}$ & $\begin{array}{c}0.086 * * * \\
(0.025)\end{array}$ \\
\hline Observations & 1,439 & 1,412 & 1,403 & 1,465 & 1,442 & 1,446 \\
\hline High leverage: Private bidder & $\begin{array}{c}0.056 * * \\
(0.028)\end{array}$ & $\begin{array}{c}0.040 \\
(0.029)\end{array}$ & $\begin{array}{c}0.033 \\
(0.037)\end{array}$ & $\begin{array}{c}-0.013 \\
(0.021)\end{array}$ & $\begin{array}{c}-0.013 \\
(0.025)\end{array}$ & $\begin{array}{c}-0.059 * * \\
(0.025)\end{array}$ \\
\hline Observations & 1,402 & 1,375 & 1,354 & 1,453 & 1,395 & 1,394 \\
\hline
\end{tabular}




\section{Table 12: Subsequent listing and organizational form}

The table reports comparisons of operating performance changes, $\Delta \operatorname{ROA}(1,+j)$ and $\Delta \operatorname{ATO}(1,+j)$ $(j=1,2,3)$, around acquisition deals between private and public bidders using a matching estimator with further regression adjustment. In Panel A the sample excludes all bidders changing their listing status in the 3 years following the deal. In Panel B the sample is split according to whether the ultimate parent of the private bidder is public. In Panel $\mathrm{C}$ the sample is split according to whether the private bidder is currently or previously backed by a PE group. The matching estimator is implemented by regressing the outcome variable on the private bidder indicator, control variables, and a fixed effect that uniquely identifies each private bidder and its matched public bidder(s) (stack fixed effects). Each stack is weighted equally (private bidders receive the weight of 1 , public bidders receive the weight of $1 / n$, where $n$ is the number of control public bidders in the stack). Standard errors clustered at the stack level are reported in parentheses. Symbols $*$, **, or $* * *$ denote statistical significance at the $10 \%, 5 \%$, or $1 \%$ level, respectively. Only the coefficients of interests are shown. The specifications are otherwise identical to those in Table 5. All variables are defined in the Appendix.

\begin{tabular}{|c|c|c|c|c|c|c|}
\hline & \multicolumn{3}{|c|}{$\Delta \mathrm{ROA}$} & \multicolumn{3}{|c|}{$\Delta$ АTO } \\
\hline & $(-1,+1)$ & $(-1,+2)$ & $(-1,+3)$ & $(-1,+1)$ & $(-1,+2)$ & $(-1,+3)$ \\
\hline \multicolumn{7}{|c|}{ Panel A: Firms not changing listing status following takeovers } \\
\hline Private bidder & $\begin{array}{c}0.081 * * * \\
(0.019)\end{array}$ & $\begin{array}{l}0.101 * * * \\
(0.024)\end{array}$ & $\begin{array}{c}0.073 * * * \\
(0.027)\end{array}$ & $\begin{array}{c}0.071 * * * \\
(0.013)\end{array}$ & $\begin{array}{l}0.094 * * * \\
(0.015)\end{array}$ & $\begin{array}{c}0.091 * * * \\
(0.019)\end{array}$ \\
\hline Observations & 3,600 & 3,560 & 3,501 & 3,655 & 3,575 & 3,551 \\
\hline \multicolumn{7}{|c|}{ Panel B: Public parent ownership of private bidders } \\
\hline Public parent: Private bidder & $\begin{array}{c}0.046 \\
(0.042)\end{array}$ & $\begin{array}{c}0.068 \\
(0.055)\end{array}$ & $\begin{array}{c}0.019 \\
(0.057)\end{array}$ & $\begin{array}{l}0.056 * * \\
(0.027)\end{array}$ & $\begin{array}{l}0.056^{*} \\
(0.033)\end{array}$ & $\begin{array}{l}-0.008 \\
(0.036)\end{array}$ \\
\hline Observations & 1,080 & 1,061 & 1,022 & 1,081 & 1,058 & 1,046 \\
\hline No public parent: Private bidder & $\begin{array}{c}0.093 * * * \\
(0.019)\end{array}$ & $\begin{array}{l}0.090 * * * \\
(0.024)\end{array}$ & $\begin{array}{c}0.070 * * * \\
(0.027)\end{array}$ & $\begin{array}{c}0.052 * * * \\
(0.013)\end{array}$ & $\begin{array}{l}0.061 * * * \\
(0.015)\end{array}$ & $\begin{array}{c}0.061 * * * \\
(0.017)\end{array}$ \\
\hline Observations & 3,196 & 3,165 & 3,143 & 3,255 & 3,194 & 3,184 \\
\hline \multicolumn{7}{|c|}{ Panel C: Private equity ownership of private bidders } \\
\hline PE backed: Private bidder & $\begin{array}{c}0.084 * * * \\
(0.020)\end{array}$ & $\begin{array}{l}0.085^{* * * *} \\
(0.025)\end{array}$ & $\begin{array}{l}0.066 * * \\
(0.028)\end{array}$ & $\begin{array}{c}0.049 * * * \\
(0.013)\end{array}$ & $\begin{array}{c}0.063 * * * \\
(0.015)\end{array}$ & $\begin{array}{l}0.043^{* *} \\
(0.017)\end{array}$ \\
\hline Observations & 3,591 & 3,538 & 3,478 & 3,604 & 3,537 & 3,513 \\
\hline Non-PE backed: Private bidder & $\begin{array}{c}0.058 \\
(0.053)\end{array}$ & $\begin{array}{l}0.135^{*} \\
(0.081)\end{array}$ & $\begin{array}{c}0.045 \\
(0.065)\end{array}$ & $\begin{array}{c}0.070 * * * \\
(0.024)\end{array}$ & $\begin{array}{c}0.057 \\
(0.037)\end{array}$ & $\begin{array}{l}0.110^{* *} \\
(0.045)\end{array}$ \\
\hline Observations & 685 & 688 & 687 & 732 & 715 & 717 \\
\hline
\end{tabular}




\section{A Appendix}

\section{Table A.1: Variable definitions}

All variables are from Capital IQ unless otherwise noted.

\begin{tabular}{|c|c|}
\hline Variable & Definition \\
\hline \multicolumn{2}{|c|}{ Key dependent variables } \\
\hline$\Delta \operatorname{ROA}_{(}(1,+j)$ & $\begin{array}{l}\text { Percentage change in ROA margin, defined as } \operatorname{ROA}(+\mathrm{j}) \text { minus } \\
\operatorname{ROA}(\underline{1}) \text {, scaled by the absolute value of } \operatorname{ROA}(1)_{2} \text { where year } \\
+\mathrm{j} \text { is the } \mathrm{j} \text { 'th year following the deal }\end{array}$ \\
\hline$\Delta \operatorname{ATO}\left({ }_{-} 1,+j\right)$ & $\begin{array}{l}\text { Percentage change in ATO margin, defined as ATO }(+\mathrm{j}) \text { minus } \\
\text { ATO }(1) \text {, scaled by the absolute value of ATO }(1)_{2} \text { where year } \\
+\mathrm{j} \text { is the } \mathrm{j} \text { 'th year following the deal }\end{array}$ \\
\hline$\Delta \operatorname{ROS}\left({ }_{-} 1,+j\right)$ & $\begin{array}{l}\text { Percentage change in ROS margin, defined as } \operatorname{ROS}(+\mathrm{j}) \text { minus } \\
\operatorname{ROS}(1) \text {, scaled by the absolute value of } \operatorname{ROS}(1)_{2} \text { where year } \\
+\mathrm{j} \text { is the } \mathrm{j} \text { 'th year following the deal }\end{array}$ \\
\hline \multicolumn{2}{|c|}{ Firm and deal characteristics } \\
\hline Total assets & $\begin{array}{l}\text { Total Assets from Capital IQ, reported in CPI-adjusted } 2009 \text { mil- } \\
\text { lions of dollars }\end{array}$ \\
\hline Total revenue & $\begin{array}{l}\text { Total revenue from Capital IQ, reported in CPI-adjusted } 2009 \text { mil- } \\
\text { lions of dollars }\end{array}$ \\
\hline Operating income & $\begin{array}{l}\text { Total Revenue less Cost of Goods Sold and Selling General \& Ad- } \\
\text { min Exp, reported in CPI-adjusted } 2009 \text { millions of dollars }\end{array}$ \\
\hline Return on assets (ROA) & Operating income scaled by total assets \\
\hline Asset turnover (ATO) & Total revenue scaled by total assets \\
\hline Return on sales (ROS) & Operating income scaled by total revenue \\
\hline Leverage & Long term debt scaled by total assets \\
\hline Cash & Total Cash \& shot-term investments scaled by total assets \\
\hline Age & Firm's age since the year founded \\
\hline Segment & Number of business segments \\
\hline Tangibility & Net property, plant \& equipment scaled by total assets \\
\hline Capital expenditure & Capital expenditure scaled by total assets \\
\hline $\mathrm{R} \& \mathrm{D}$ & $R \& D$ expenditure scaled by total assets \\
\hline Sales growth & $\begin{array}{l}\text { Annual increase in total revenue scaled by beginning-of-year total } \\
\text { revenue }\end{array}$ \\
\hline Deal value & $\begin{array}{l}\text { Total transaction value, reported in CPI-adjusted } 2009 \text { millions of } \\
\text { dollars }\end{array}$ \\
\hline Relative size & Deal value scaled by Total Assets of the bidder \\
\hline Private target & $\begin{array}{l}\text { Indicator variable taking the value of one if the target firm is pri- } \\
\text { vate, and zero otherwise }\end{array}$ \\
\hline Non-US target & $\begin{array}{l}\text { Indicator variable taking the value of one if the target firm is non- } \\
\text { US, and zero otherwise }\end{array}$ \\
\hline
\end{tabular}




\section{Table A.1: Variable definitions (continued)}

\begin{tabular}{|c|c|}
\hline Variable & Definition \\
\hline Hostile & $\begin{array}{l}\text { Indicator variable taking the value of one if the deal is reported as } \\
\text { hostile, and zero otherwise }\end{array}$ \\
\hline Solicited & $\begin{array}{l}\text { Indicator variable taking the value of one if the the deal is reported } \\
\text { as solicited, and zero otherwise }\end{array}$ \\
\hline Diversifying & $\begin{array}{l}\text { Indicator variable taking the value of one if the bidder and the tar- } \\
\text { get do not share the same two-digit SIC code, and zero otherwise }\end{array}$ \\
\hline Deal order & The number of deals conducted by the bidder up to that point \\
\hline \multicolumn{2}{|c|}{ Financing constraints proxies } \\
\hline SA Index & $\begin{array}{l}(0.737 \times \text { Size })+\left(0.043 \times \text { Size }^{2}\right)(0.040 \times \text { Age }) \text {, where Size } \\
\text { is the log of book assets, and Age is the number of years from } \\
\text { foundation. Size is capped at the log of } \$ 4.5 \text { billion, and age is } \\
\text { capped at } 37 \text { years following Hadlock and Pierce }(2010) \text {. Note: } \\
\text { in Hadlock and Pierce }(2010) \text { age is measured as the number of } \\
\text { years with non-missing stock price in Compustat; we replace this } \\
\text { with the year of foundation since private firms do not have a stock } \\
\text { listing. }\end{array}$ \\
\hline Free cash flow (FCF) & $\begin{array}{l}\text { Operating income minus interest minus tax minus dividends paid, } \\
\text { scaled by total assets }\end{array}$ \\
\hline Leverage & Book value of long term debt scaled by book value of total assets \\
\hline \multicolumn{2}{|l|}{ Governance proxies } \\
\hline Takeover Defence Score & $\begin{array}{l}\text { Index of } 24 \text { corporate governance provisions, scaled to range from } \\
\text { zero to one, with higher values indicating greater limits to share- } \\
\text { holder rights }\end{array}$ \\
\hline CEO Ownership & $\begin{array}{l}\text { Fraction of company shares owned by the CEO (available from } \\
\text { year 2000). Data from Huasheng Gao (NTU). }\end{array}$ \\
\hline Outside Top1 Ownership & $\begin{array}{l}\text { Fraction of company shares owned by the top } 1 \text { outside shareholder } \\
\text { (available from year 2000). Data from Huasheng Gao (NTU). }\end{array}$ \\
\hline \multicolumn{2}{|c|}{ Instrument for private status } \\
\hline VCsupply at founding & $\begin{array}{l}\text { Number of firms receiving first-round VC funding in the firm's } \\
\text { headquarter state two years after the firm was founded, scaled by } \\
\text { the number of firms in the state that were less than three years old } \\
\text { at that time. VC data is from VenureExpert, and the number of } \\
\text { firms less than three years old is from the Longitudinal Business } \\
\text { Database of the U.S. Census Bureau. We obtain this variable di- } \\
\text { rectly from the authors of the Asker, Farre-Mensa, and Ljungqvist } \\
\text { (2015) study. }\end{array}$ \\
\hline
\end{tabular}


Table A.2: Summary statistics on bidders vs. all firms in Capital IQ

The table presents comparisons of firm characteristics between bidders and the universe of firms in Capital IQ. Panel A reports the statistics for private firms and Panel B for public firms. Symbols ***,**, and * next to the means and medians indicate statistically significant differences between private (public) bidders and the universe of private (public) firms at the $1 \%, 5 \%$ and $10 \%$ levels, respectively. All variables are defined in the Appendix.

\begin{tabular}{|c|c|c|c|c|c|c|c|c|c|c|}
\hline & \multicolumn{5}{|c|}{ Bidders in Capital IQ } & \multicolumn{5}{|c|}{ All Capital IQ firms } \\
\hline & Mean & Median & Std & $\mathrm{p} 25$ & p75 & Mean & Median & Std & $\mathrm{p} 25$ & p75 \\
\hline \multicolumn{11}{|c|}{ Panel A: Private firms } \\
\hline Total assets $(\$ \mathrm{~m})$ & $4306.490 * * *$ & $661.632 * * *$ & 12394.703 & 211.290 & 1879.355 & 1704.181 & 327.586 & 3721.354 & 51.318 & 1252.963 \\
\hline Operating income $(\$ \mathrm{~m})$ & $431.900 * * *$ & $70.189 * * *$ & 1278.12 & 24.656 & 177.849 & 97.277 & 17.320 & 235.021 & 0.415 & 70.142 \\
\hline Return on assets & $0.204 * * *$ & $0.106 * * *$ & 0.396 & 0.065 & 0.170 & 0.066 & 0.062 & 0.141 & 0.013 & 0.114 \\
\hline Asset turnover & $0.948 * * *$ & $0.751 * * *$ & 0.823 & 0.369 & 1.193 & 1.279 & 0.986 & 1.070 & 0.534 & 1.645 \\
\hline Return on sales & $0.222 * * *$ & $0.166 * * *$ & 0.314 & 0.078 & 0.336 & 0.075 & 0.066 & 0.150 & 0.015 & 0.138 \\
\hline Leverage & $0.425 * * *$ & 0.444 & 0.331 & 0.141 & 0.610 & 0.471 & 0.436 & 0.379 & 0.163 & 0.680 \\
\hline Cash & 0.097 & 0.040 & 0.148 & 0.012 & 0.104 & 0.102 & 0.041 & 0.148 & 0.013 & 0.117 \\
\hline Age & $33.689 *$ & $20.000 * * *$ & 35.776 & 8.000 & 45.000 & 32.616 & 16.000 & 38.087 & 6.000 & 45.000 \\
\hline Segment & $1.635 * * *$ & $1.000 * * *$ & 1.355 & 1.000 & 1.000 & 1.187 & 1.000 & 0.784 & 1.000 & 1.000 \\
\hline Tangibility & $0.266 * * *$ & $0.189 * * *$ & 0.243 & 0.070 & 0.401 & 0.313 & 0.232 & 0.266 & 0.089 & 0.488 \\
\hline Capital expenditure & $0.052 * *$ & $0.026 * * *$ & 0.076 & 0.007 & 0.061 & 0.059 & 0.036 & 0.068 & 0.017 & 0.072 \\
\hline $\mathrm{R} \& \mathrm{D}$ & $0.014 * * *$ & $0.000 * * *$ & 0.040 & 0.000 & 0.002 & 0.022 & 0.000 & 0.065 & 0.000 & 0.000 \\
\hline Sales growth & $0.372 * * *$ & $0.129 * * *$ & 0.813 & 0.030 & 0.379 & 0.248 & 0.077 & 0.584 & -0.008 & 0.266 \\
\hline \multicolumn{11}{|c|}{ Panel B: Public firms } \\
\hline Total assets $(\$ \mathrm{~m})$ & $7209.538 * * *$ & $1383.207 * * *$ & 16147.945 & 457.076 & 4943.567 & 3201.868 & 573.534 & 7383.611 & 148.173 & 2204.28 \\
\hline Operating income $(\$ \mathrm{~m})$ & $1241.960 * * *$ & $177.179 * * *$ & 3234.455 & 50.923 & 649.235 & 327.296 & 45.943 & 833.882 & 5.152 & 207.000 \\
\hline Return on assets & $0.150 * * *$ & $0.136 * * *$ & 0.089 & 0.090 & 0.196 & 0.083 & 0.086 & 0.099 & 0.037 & 0.138 \\
\hline Asset turnover & $1.003 * * *$ & $0.838 * * *$ & 0.679 & 0.534 & 1.249 & 1.185 & 1.018 & 0.745 & 0.649 & 1.518 \\
\hline Return on sales & $0.207 * * *$ & $0.164 * * *$ & 0.159 & 0.093 & 0.294 & 0.088 & 0.082 & 0.121 & 0.032 & 0.146 \\
\hline Leverage & $0.214 * * *$ & $0.190 * * *$ & 0.184 & 0.047 & 0.325 & 0.201 & 0.170 & 0.188 & 0.019 & 0.316 \\
\hline Cash & 0.163 & 0.097 & 0.171 & 0.031 & 0.240 & 0.165 & 0.097 & 0.176 & 0.029 & 0.242 \\
\hline Age & 47.585 & $32.000 * * *$ & 39.851 & 17.000 & 73.000 & 47.300 & 33.000 & 37.471 & 19.000 & 67.000 \\
\hline Segment & $3.318 * * *$ & $3.000 * * *$ & 1.701 & 3.000 & 4.000 & 2.963 & 3.000 & 1.969 & 1.000 & 4.000 \\
\hline Tangibility & $0.224 * * *$ & $0.145 * * *$ & 0.216 & 0.069 & 0.302 & 0.255 & 0.188 & 0.217 & 0.086 & 0.362 \\
\hline Capital expenditure & $0.045 * * *$ & $0.030 * * *$ & 0.047 & 0.016 & 0.055 & 0.053 & 0.035 & 0.053 & 0.018 & 0.066 \\
\hline $\mathrm{R} \& \mathrm{D}$ & $0.031 * * *$ & $0.003 * * *$ & 0.046 & 0.000 & 0.049 & 0.027 & 0.000 & 0.051 & 0.000 & 0.034 \\
\hline Sales growth & $0.164 * * *$ & $0.114 * * *$ & 0.272 & 0.025 & 0.247 & 0.127 & 0.083 & 0.255 & -0.005 & 0.203 \\
\hline
\end{tabular}




\section{TableA.3: Operating performance changes in the population of Capital IQ firms}

This table reports mean differences in operating performance changes ( $\triangle$ ROA and $\Delta$ ATO) between private and public firms in the universe of Capital IQ firms, using both full sample and matched firm comparisons. Matched firms are closest in size (total assets) and come from the same industry (2-digit SIC code) and year. Year 0 represents current fiscal year and year $+i$ the $i$ th year after. Symbols $* * *, * *$, and $*$ denote statistical significance at the $1 \%, 5 \%$ and $10 \%$ levels, respectively.

\begin{tabular}{lccc}
\hline & \multicolumn{3}{c}{ From year $i$ to year $j$} \\
Percentage changes & 0 to +1 & 0 to +2 & 0 to +3 \\
\hline \multicolumn{4}{c}{ Panel A: Private firms - Public firms } \\
$\Delta$ Return on assets (ROA) & 0.036 & -0.088 & $-0.148^{* *}$ \\
$\Delta$ Asset turnover (ATO) & 0.013 & -0.009 & 0.006 \\
\hline & Panel B: Private firms - Matched public firms \\
$\Delta$ Return on assets (ROA) & -0.004 & -0.124 & -0.161 \\
$\Delta$ Asset turnover (ATO) & -0.007 & 0.018 & 0.024 \\
\hline
\end{tabular}




\section{Table A.4: Governance characteristics across private and public bidders}

The table presents descriptive statistics for firm-level governance characteristics of public and private bidders. CEO ownership is the fraction of company shares owned by the CEO (available from year 2000). Outside Top 1 Ownership is the fraction of company shares owned by the top 1 outside shareholder (available from year 2004). Takeover Defence Score is an index of 24 corporate governance provisions from Capital IQ, scaled to range from 0 to 1 , with higher values indicating stronger limits to shareholder rights. Symbols *,**, and $* * *$ denote statistically significant differences between public and private bidders at the $10 \%, 5 \%$, and $1 \%$ level, respectively.

\begin{tabular}{lcccccccc}
\hline & \multicolumn{3}{c}{ Private Bidders } & & \multicolumn{3}{c}{ Public Bidders } \\
\cline { 2 - 3 } \cline { 7 - 9 } & Mean & Median & Obs. & & Mean & Median & Obs. \\
\hline CEO Ownership & 0.092 & 0.040 & 765 & & & $0.043^{* * *}$ & $0.006^{* * *}$ & 6,835 \\
Outside Top1 Ownership & 0.462 & 0.438 & 422 & & & $0.112^{* * *}$ & $0.084^{* * *}$ & 5,264 \\
Takeover defence score & 0.237 & 0.210 & 1,176 & & & $0.320^{* * *}$ & $0.310^{* * * *}$ & 7,125 \\
\hline
\end{tabular}




\section{Table A.5: Analysis using percentage point changes}

The table reports comparisons of unscaled operating performance changes around acquisition deals between private and public bidders in the full sample (Panel A) as well as using a matching estimator with and without further regression adjustment (Panels B and C). Year_1 is the last fiscal year prior to deal completion. Year $+i$ is the $i$ th fiscal year after deal completion. Industry-adjusted performance changes are net of the contemporaneous median performance change of all firms in the bidder's 2-digit SIC industry. Bidders are purged from the computation of industry medians. Control-firm-adjusted performance changes are net of the contemporaneous performance change of a control firm. Control firms with the level of pre-deal ROA closest to that of the bidder are selected from the same 2-digit SIC industry, year, and private/public type. The matching estimator is implemented by regressing the outcome variable on the private bidder indicator (with or without controls) and a fixed effect that uniquely identifies each private bidder and its matched public bidder(s) (stack fixed effects). Each stack is weighted equally (private bidders receive the weight of 1, public bidders receive the weight of $1 / n$, where $n$ is the number of control public bidders in the stack). Standard errors clustered at the stack level are reported in parentheses. Symbols $* * *$, or $* * *$ denote statistical significance at the $10 \%, 5 \%$, or $1 \%$ level, respectively. Only the coefficients of interests are shown. The specifications are otherwise identical to those in Table 5. All variables are defined in the Appendix.

\begin{tabular}{|c|c|c|c|}
\hline \multicolumn{4}{|c|}{ Panel A: Full sample comparisons } \\
\hline & \multicolumn{3}{|c|}{ From year $i$ to year $j$} \\
\hline & -1 to +1 & -1 to +2 & -1 to +3 \\
\hline & \multicolumn{3}{|c|}{ Private bidder } \\
\hline$\Delta$ Return on assets (ROA) & $0.0079 * * *$ & $0.0054 *$ & 0.0027 \\
\hline$\Delta$ Asset turnover (ATO) & $0.0099 * * *$ & $0.0049 * * *$ & $0.0032 * * *$ \\
\hline Industry-adjusted $\Delta \mathrm{ROA}$ & $0.0049 * * *$ & $0.0055^{* * *}$ & $-0.0023 * *$ \\
\hline Industry-adjusted $\Delta$ ATO & $0.0099 * * *$ & $0.0074 * * *$ & $-0.0014 *$ \\
\hline Control-firm-adjusted $\Delta \mathrm{ROA}$ & 0.0049 & $0.0082 * *$ & $0.0091 *$ \\
\hline \multirow[t]{2}{*}{ Control-firm-adjusted $\Delta$ ATO } & $0.0216^{*}$ & $0.0181 *$ & $0.0368 * *$ \\
\hline & \multicolumn{3}{|c|}{ Public bidder } \\
\hline$\Delta$ Return on assets (ROA) & $-0.0116^{* * *}$ & $-0.0149 * * *$ & $-0.0189 * * *$ \\
\hline$\Delta$ Asset turnover (ATO) & $-0.0107 * * *$ & $-0.0239 * * *$ & $-0.0327 * * *$ \\
\hline Industry-adjusted $\Delta \mathrm{ROA}$ & $-0.0123 * * *$ & $-0.0146 * * *$ & $-0.0171 * * *$ \\
\hline Industry-adjusted $\Delta \mathrm{ATO}$ & $-0.0219 * * *$ & $-0.0275^{* * *}$ & $-0.0221 * * *$ \\
\hline Control-firm-adjusted $\Delta \mathrm{ROA}$ & $-0.0107 * * *$ & $-0.0065^{* * *}$ & $-0.0029 * *$ \\
\hline Control-firm-adjusted $\Delta$ ATO & $-0.0177 * * *$ & $-0.0083 * *$ & 0.0030 \\
\hline \multicolumn{4}{|c|}{ Private bidder - Public bidder } \\
\hline$\Delta$ Return on assets (ROA) & $0.0195 * * *$ & $0.0203^{* * *}$ & $0.0216^{* * *}$ \\
\hline$\Delta$ Asset turnover (ATO) & $0.0206^{* * *}$ & $0.0288^{* * *}$ & $0.0359 * * *$ \\
\hline Industry-adjusted $\Delta \mathrm{ROA}$ & $0.0172 * * *$ & $0.0201 * * *$ & $0.0148 * * *$ \\
\hline Industry-adjusted $\Delta$ ATO & $0.0318 * * *$ & $0.0349 * * *$ & $0.0207 * * *$ \\
\hline Control-firm-adjusted $\Delta$ ROA & $0.0156^{* * *}$ & $0.0147 * * *$ & $0.0120^{*}$ \\
\hline Control-firm-adjusted $\Delta$ ATO & $0.0393 * * *$ & $0.0264 * *$ & $0.0338 * *$ \\
\hline
\end{tabular}


Table A.5: continued

\begin{tabular}{|c|c|c|c|c|c|c|}
\hline & \multicolumn{3}{|c|}{$\Delta \mathrm{ROA}$} & \multicolumn{3}{|c|}{$\triangle \mathrm{ATO}$} \\
\hline & $(-1,+1)$ & $(-1,+2)$ & $(-1,+3)$ & $(-1,+1)$ & $(-1,+2)$ & $(-1,+3)$ \\
\hline \multicolumn{7}{|c|}{ Panel B: Matching estimator: univariate } \\
\hline Private-public & $0.0085 * * *$ & $0.0123 * * *$ & $0.0152 * * *$ & $0.0302 * * *$ & $0.0427 * * *$ & $0.0405^{* * *}$ \\
\hline \multicolumn{7}{|c|}{ Panel C: Matching estimator: regression adjustment } \\
\hline Private bidder & $\begin{array}{c}0.005 * * \\
(0.003)\end{array}$ & $\begin{array}{c}0.007 * * \\
(0.003)\end{array}$ & $\begin{array}{c}0.003 \\
(0.003)\end{array}$ & $\begin{array}{c}0.028 * * * \\
(0.008)\end{array}$ & $\begin{array}{c}0.036 * * * \\
(0.009)\end{array}$ & $\begin{array}{c}0.029 * * \\
(0.011)\end{array}$ \\
\hline Observations & 4,298 & 4,282 & 4,176 & 4,341 & 4,296 & 4,238 \\
\hline
\end{tabular}




\section{Table A.6: Analysis using median percentage changes}

The table reports comparisons of median operating performance changes around acquisition deals between private and public bidders in the full sample (Panel A) as well as using a matching estimator with and without further regression adjustment (Panels B and C). Year_1 is the last fiscal year prior to deal completion. Year $+i$ is the $i$ th fiscal year after deal completion. Industry-adjusted performance changes are net of the contemporaneous median performance change of all firms in the bidder's 2-digit SIC industry. Bidders are purged from the computation of industry medians. Control-firm-adjusted performance changes are net of the contemporaneous performance change of a control firm. Control firms with the level of pre-deal ROA closest to that of the bidder are selected from the same 2-digit SIC industry, year, and private/public type. The matching estimator is implemented by regressing (using quantile regressions estimated at the median) the outcome variable on the private bidder indicator (with or without controls) and a fixed effect that uniquely identifies each private bidder and its matched public bidder(s) (stack fixed effects). Each stack is weighted equally (private bidders receive the weight of 1 , public bidders receive the weight of $1 / n$, where $n$ is the number of control public bidders in the stack). Standard errors clustered at the stack level are reported in parentheses. Symbols *,**, or *** denote statistical significance at the $10 \%, 5 \%$, or $1 \%$ level, respectively. Only the coefficients of interests are shown. The specifications are otherwise identical to those in Table 5. All variables are defined in the Appendix.

Panel A: Full sample comparisons

From year $i$ to year $j$

\begin{tabular}{|c|c|c|c|}
\hline & \multicolumn{3}{|c|}{ Private bidder } \\
\hline$\Delta$ Return on assets (ROA) & $0.0106^{* *}$ & 0.0092 & -0.0121 \\
\hline$\Delta$ Asset turnover (ATO) & $0.0099 *$ & $0.0144 * * *$ & $0.0081 * *$ \\
\hline Industry-adjusted $\Delta \mathrm{ROA}$ & $0.0222 *$ & $0.0196^{*}$ & $0.0044 * *$ \\
\hline Industry-adjusted $\Delta$ ATO & 0.0086 & $0.0126 * *$ & $0.0185^{* * *} *$ \\
\hline Control-firm-adjusted $\Delta \mathrm{ROA}$ & 0.0193 & 0.0184 & 0.0173 \\
\hline \multirow[t]{2}{*}{ Control-firm-adjusted $\Delta$ ATO } & $0.0227 *$ & $0.0195 *$ & $0.0581 * *$ \\
\hline & \multicolumn{3}{|c|}{ Public bidder } \\
\hline$\Delta$ Return on assets (ROA) & $-0.0215 * * *$ & $-0.0382 * * *$ & $-0.0324 * * *$ \\
\hline$\triangle$ Assel turnuver (AIU) & $-0.0 \angle 32 \cdots n$ & $-U .0<24 \cdots n$ & -0.0541 1 \\
\hline Industry-adjusted $\Delta \mathrm{ROA}$ & $-0.0234 * * *$ & $-0.0161 * * *$ & $-0.0117 * * *$ \\
\hline Industry-adjusted $\Delta \mathrm{ATO}$ & $-0.0229 * * *$ & $-0.0187 * * *$ & $-0.0121 * *$ \\
\hline Control-firm-adjusted $\Delta \mathrm{ROA}$ & $-0.0369^{* * *}$ & $-0.0112 * *$ & -0.0279 \\
\hline \multirow[t]{2}{*}{ Control-firm-adjusted $\Delta$ ATO } & $-0.0076 * *$ & $0.0049^{* *}$ & $0.0075^{* * *}$ \\
\hline & \multicolumn{3}{|c|}{$\operatorname{Pr}_{\text {vate bidder }- \text { Public bidder }}$} \\
\hline$\Delta$ Return on assets (ROA) & $0.0321 * *$ & $0.0474 * *$ & $0.0203 * *$ \\
\hline$\Delta$ Asset turnover (ATO) & $0.0331 * * *$ & $0.0368 * * *$ & $0.0422 * *$ \\
\hline Industry-adjusted $\Delta \mathrm{ROA}$ & $0.0456^{*}$ & $0.0357 *$ & $0.0161 * *$ \\
\hline Industry-adjusted $\Delta$ ATO & $0.0315^{* * *}$ & $0.0313^{* * *}$ & $0.0306 * * *$ \\
\hline Control-firm-adjusted $\Delta \mathrm{ROA}$ & $0.0562 * *$ & $0.0296 *$ & $0.0452 *$ \\
\hline Control-firm-adjusted $\Delta \mathrm{ATO}$ & $0.0303 *$ & $0.0146^{*}$ & $0.0506^{* *}$ \\
\hline
\end{tabular}


Table A.6: continued

\begin{tabular}{|c|c|c|c|c|c|c|}
\hline & \multicolumn{3}{|c|}{$\Delta \mathrm{ROA}$} & \multicolumn{3}{|c|}{$\triangle \mathrm{ATO}$} \\
\hline & $(-1,+1)$ & $(-1,+2)$ & $(-1,+3)$ & $(-1,+1)$ & $(-1,+2)$ & $(-1,+3)$ \\
\hline \multicolumn{7}{|c|}{ Panel B: Matching estimator: univariate } \\
\hline \multirow[t]{3}{*}{ Private-public } & $0.0315 * *$ & $0.0811 * * *$ & $0.0353 *$ & $0.0318 * * *$ & & \\
\hline & & $0.0530 * * *$ & \multicolumn{4}{|c|}{$0.0412 * *$ Panel C: Matching estimator: } \\
\hline & \multicolumn{3}{|c|}{ regression adjustment } & & & \\
\hline Private bidder & $\begin{array}{c}0.053 * * \\
(0.027)\end{array}$ & $\begin{array}{c}0.060 * * \\
(0.024)\end{array}$ & $\begin{array}{c}0.008 \\
(0.036)\end{array}$ & $\begin{array}{c}0.036 * * * \\
(0.009)\end{array}$ & $\begin{array}{c}0.033 * * \\
(0.013)\end{array}$ & $\begin{array}{c}0.017 \\
(0.015)\end{array}$ \\
\hline Observations & 4,276 & 4,226 & 4,165 & 4,336 & 4,252 & 4,230 \\
\hline
\end{tabular}

